\title{
Uranium Provinces of North America- Their Definition, Distribution, and Models
}

By Warren I. Finch 


\title{
U.S. DEPARTMENT OF THE INTERIOR BRUCE BABBITT, Secretary
}

\author{
U.S. GEOLOGICAL SURVEY \\ Gordon P. Eaton, Director
}

For sale by U.S. Geological Survey, Information Services

Box 25286, Federal Center

Denver, CO 80225

\begin{abstract}
Any use of trade, product, or firm names in this publication is for descriptive purposes only and does not imply endorsement by the U.S. Government
\end{abstract}

Library of Congress Cataloging-in-Publication Data

Finch, Warren Irvin, 1924-

Uranium provinces of North America : their definition, distribution, and models / by

Warren I. Finch.

p. $\quad \mathrm{cm}$. - (U.S. Geological Survey bulletin ; 2141)

Includes bibliographical references.

Supt. of Docs. no.: I 19.3:2141

1. Uranium ores-North America. I. Title. II. Series.

QE75.B9 no. 2141

[QE390.2.U7]

$557.3 \mathrm{~s}-\mathrm{dc} 20$

[551.4'932'097] 


\section{CONTENTS}

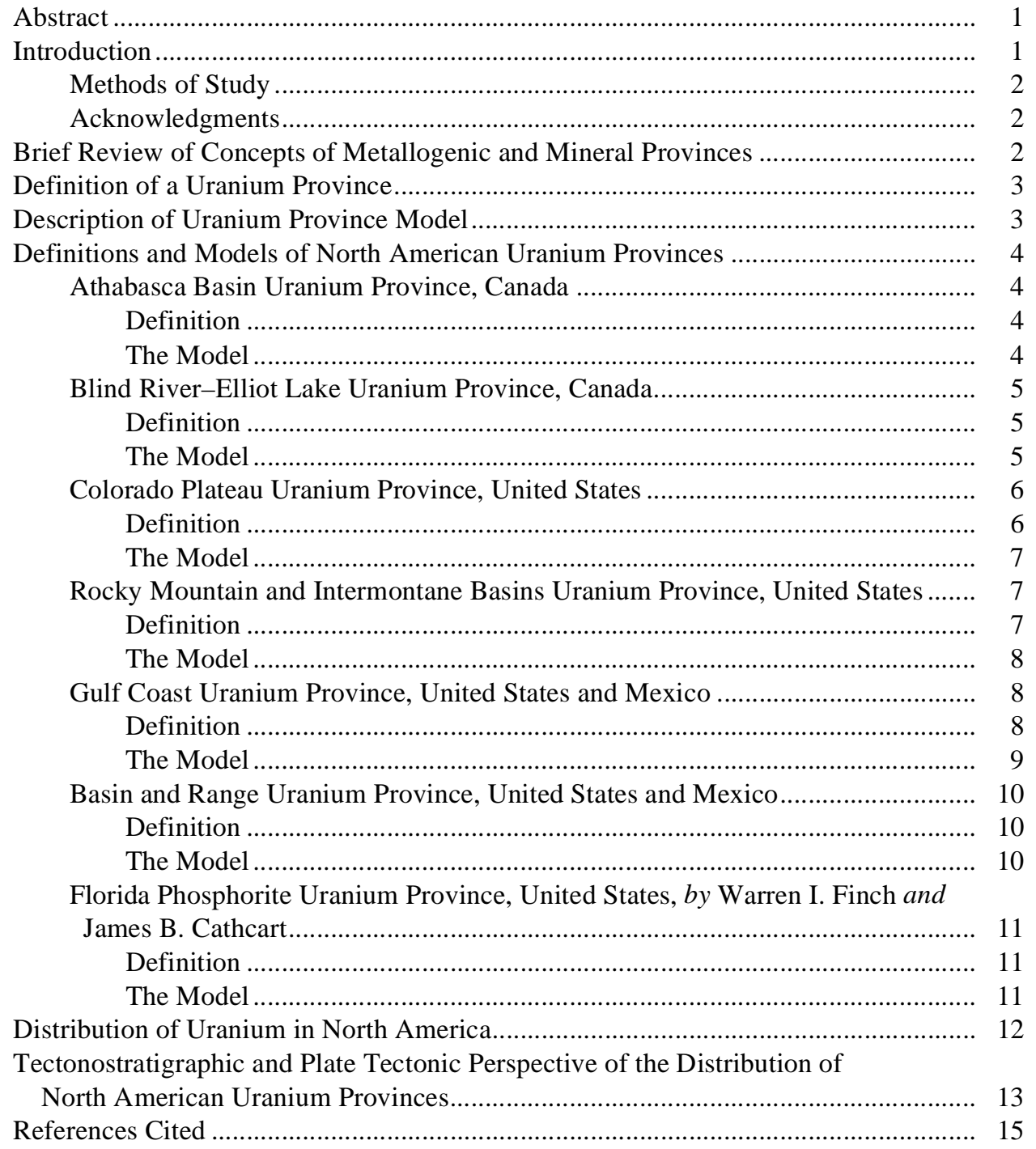

\section{PLATES}

1. Map showing locations of uranium provinces and the major uranium clusters in North America.

2. Map showing details of the Colorado Plateau, Rocky Mountain and Intermontane Basins, and Basin and Range Uranium Provinces. 


\section{FIGURES}

1-3. Maps showing:

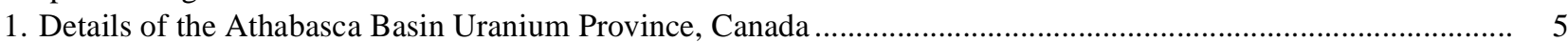

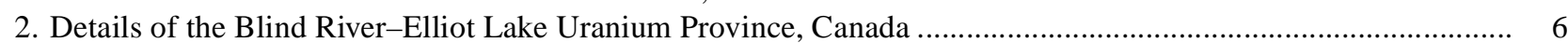

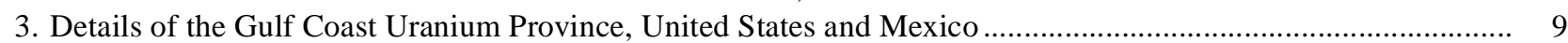

4. Graph showing distribution of uranium in North America ....................................................................... 12

\section{TABLE}

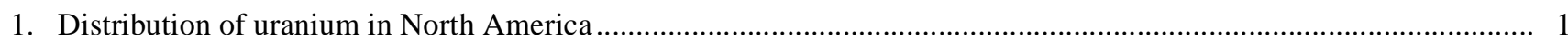




\title{
URANIUM PROVINCES OF NORTH AMERICA- THEIR DEFINITION, DISTRIBUTION, AND MODELS
}

\author{
By Warren I. Finch
}

\begin{abstract}
Uranium resources in North America are principally in unconformity-related, quartz-pebble conglomerate, sandstone, volcanic, and phosphorite types of uranium deposits. Most are concentrated in separate, well-defined metallogenic provinces. Proterozoic quartz-pebble conglomerate and unconformity-related deposits are, respectively, in the Blind River-Elliot Lake (BRELUP) and the Athabasca Basin (ABUP) Uranium Provinces in Canada. Sandstone uranium deposits are of two principal subtypes, tabular and roll-front. Tabular sandstone uranium deposits are mainly in upper Paleozoic and Mesozoic rocks in the Colorado Plateau Uranium Province (CPUP). Roll-front sandstone uranium deposits are in Tertiary rocks of the Rocky Mountain and Intermontane Basins Uranium Province (RMIBUP), and in a narrow belt of Tertiary rocks that form the Gulf Coastal Uranium Province (GCUP) in south Texas and adjacent Mexico. Volcanic uranium deposits are concentrated in the Basin and Range Uranium Province (BRUP) stretching from the McDermitt caldera at the Oregon-Nevada border through the Marysvale district of Utah and Date Creek Basin in Arizona and south into the Sierra de Peña Blanca District, Chihuahua, Mexico. Uraniferous phosphorite occurs in Tertiary sediments in Florida, Georgia, and North and South Carolina and in the Lower Permian Phosphoria Formation in Idaho and adjacent States, but only in Florida has economic recovery been successful. The Florida Phosphorite Uranium Province (FPUP) has yielded large quantities of uranium as a byproduct of the production of phosphoric acid fertilizer. Economically recoverable quantities of copper, gold, molybdenum, nickel, silver, thorium, and vanadium occur with the uranium deposits in some provinces.

Many major epochs of uranium mineralization occurred in North America. In the BRELUP, uranium minerals were concentrated in placers during the Early Proterozoic (2,500-2,250 Ma). In the ABUP, the unconformity-related deposits were most likely formed initially by hot saline formational water related to diagenesis $(\approx 1,400$ to $1,330 \mathrm{Ma})$ and later reconcentrated by hydrothermal events at
\end{abstract}

$\approx 1,280-\approx 1,000, \approx 575$, and $\approx 225 \mathrm{Ma}$. Subsequently in North America, only minor uranium mineralization occurred until after continental collision in Permian time (255 Ma). Three principal epochs of uranium mineralization occurred in the CPUP: $(1) \approx 210-200 \mathrm{Ma}$, shortly after Late Triassic sedimentation; (2) $\approx 155-150 \mathrm{Ma}$, in Late Jurassic time; and (3) $\approx 135 \mathrm{Ma}$, after sedimentation of the Upper Jurassic Morrison Formation. The most likely source of the uranium was silicic volcaniclastics for the three epochs derived from a volcanic island arc at the west edge of the North American continent. Uranium mineralization occurred during Eocene, Miocene, and Pliocene times in the RMIBUP, GCUP, and BRUP. Volcanic activity took place near the west edge of the continent during and shortly after sedimentation of the host rocks in these three provinces. Some volcanic centers in the Sierra de Peña Blanca district within the BRUP may have provided uranium-rich ash to host rocks in the GCUP.

Most of the uranium provinces in North America appear to have a common theme of close associations to volcanic activity related to the development of the western margin of the North American plate. The south and west margin of the Canadian Shield formed the leading edge of the progress of uranium source development and mineralization from the Proterozoic to the present. The development of favorable hosts and sources of uranium is related to various tectonic elements developed over time. Periods of major uranium mineralization in North America were Early Proterozoic, Middle Proterozoic, Late Triassic-Early Jurassic, Early Cretaceous, Oligocene, and Miocene. Tertiary mineralization was the most pervasive, covering most of Western and Southern North America.

\section{INTRODUCTION}

The uranium provinces of North America have been defined, described, and modeled in order to demonstrate the distribution of uranium resources, identify regional aspects of the genesis of uranium deposits, identify broad exploration guides, and provide a basis for the assessment of environmental impacts of natural concentrations of uranium and 
attendant exploration, mining, and milling activities. The provinces are identified by the distribution of major uranium clusters, ${ }^{1}$ generally of a size of 500 tons and more $\mathrm{U}_{3} \mathrm{O}_{8}$, commonly of only a few types of uranium deposits related genetically in time and space. Their boundaries are defined on regional geotectonic features related to the distribution of uranium clusters and their host rocks. The uranium province model format presented here for the first time is designed to provide the major characteristics of the province in brief concise descriptions.

The study of the plate tectonic history of North America has revealed that most of the uranium provinces appear to have been related to the tectonic evolution of the western active margin of the North American plate. Volcanic activity along the western margin of the plate has contributed both direct and indirect sources of uranium for the uranium clusters in the provinces.

\section{METHODS OF STUDY}

In order to identify, define, describe, and model the uranium provinces, a compilation was made of large uranium clusters, specifically those with a size of 500 or more tons $\mathrm{U}_{3} \mathrm{O}_{8}$, in the United States, Canada, and Mexico.

The uranium cluster data consisting of name, country, State or Province, latitude and longitude, size, grade, and deposit type are compiled into a computer data base. The sources of the size and grade data include published reports, U.S. Department of Energy and U.S. Geological Survey file data, Nuclear Fuel and Rocky Mountain Scout newsletters, company press releases, and data files of the German Federal Institute for Geosciences and Raw Materials; many of these data are part of the International Atomic Energy Agency "Working Material for the World Atlas of Uranium Deposits" (Finch and others, 1995). The maps in plates 1 and 2 and figures 1-3 were made using the GSMAP software package (Selner and Taylor, 1992).

From the distribution of large uranium clusters, the provinces were identified and defined by the tectonogeologic features related to the distribution of host rocks and the genetic history of the formation of the clusters of uranium deposits. Although large uranium clusters were mainly used to identify uranium provinces, the borders of

\footnotetext{
${ }^{1} \mathrm{~A}$ uranium cluster is defined as the group of all the uranium deposits (properties) within an area of about 25 square miles (about 64 square kilometers) (Finch, 1991). A cluster commonly consists of more than one deposit and is named for the largest deposit, most well known deposit, district name, or geographic name. Ideally, the size and grade of a cluster are the total tons of $\mathrm{U}_{3} \mathrm{O}_{8}$ and the average grade of the "geologic" deposit based on uranium endowment at a cutoff of about 0.03 percent $\mathrm{U}_{3} \mathrm{O}_{8}$. In practice, the size and grade are based on reserves and production data that are in turn based on higher grade cutoffs.
}

the provinces are extended beyond the major clusters by the distribution of smaller clusters, for example, the Colorado Plateau Uranium Province (CPUP) as shown by Finch (1991). Detailed studies underway for the Rocky Mountain and Intermontane Basins Uranium Province (RMIBUP) and Gulf Coast Uranium Province (GCUP), and Basin and Range Uranium Province (BRUP) provided the distribution of smaller clusters needed to fully define these provinces.

The initial study of uranium provinces in North America was conducted mainly in the summer of 1992 to prepare a poster for the 29th International Geological Congress held in Kyoto, Japan, August 26-September 5 (Finch, 1992a). The study has provided input data for the "Consultancy on the Preparation of World Atlas of Uranium Deposits" (International Atomic Energy Agency, Vienna, Austria).

\section{ACKNOWLEDGMENTS}

The preparation of the cluster and province outline data files for using the GSMAP software was greatly aided by Richard B. Taylor. Charles T. Pierson was very helpful in plotting the final maps.

\section{BRIEF REVIEW OF CONCEPTS OF METALLOGENIC AND MINERAL PROVINCES}

Traditionally, a metallogenic province is generally defined by the occurrence of one or more specific kinds of mineral deposits in a region with distinct petrographic and tectonic features, commonly related to the history of the Earth's crust. A metallogenic province is commonly referred to as a mineral province. An early reference to uranium provinces was by Klepper and Wyant (1956), who pointed out that exploitable uranium deposits resulted from original inhomogeneities of uranium in the Earth's crust that commonly persisted through long periods of time, and later interplays of orogenic, metamorphic, and sedimentary processes produced rocks with enriched uranium. The initial enriched uranium was successively remobilized and concentrated into new enrichments of one or more magnitudes above normal background forming uranium ore deposits. The source of the uranium and the geologic and geochemical processes were generally closely related; this concept is commonly thought of as a metallogeny.

In 1985, a "Technical Committee Meeting of the International Atomic Energy Agency on the Recognition of Uranium Provinces" held in London, England, reviewed concepts of Uranium Provinces (International Atomic 
Energy Agency, 1988). As part of the meeting, panel members defined a uranium province as "A region of the Earth's crust in which rocks of one or more successive ages are enriched in uranium above normal abundance, generally as distinct deposits***" (Ferguson and others, 1988, p. 439). As a member of that panel, I pointed out the anomalous Colorado Plateau Uranium Province where the most likely source of uranium was far removed from the western boundary of the province (Granger and Finch, 1988). Study of other sedimentary uranium provinces in North America has revealed similar situations.

\section{DEFINITION OF A URANIUM PROVINCE}

The "traditional" concept of a uranium province is modified for this study. A uranium province is defined more narrowly as a large geologically and tectonically distinct region where substantial uranium is concentrated into clusters and the uranium is recovered either economically as the sole commodity or as a byproduct of another commodity, such as gold and phosphate. For purposes of this study, the clusters must have a minimum of 500 tons of contained $\mathrm{U}_{3} \mathrm{O}_{8}$. The province can be defined geologically as a structural or tectonic unit, such as a very large prominent basin, a group of interrelated basins, orogenic belt, geophysiographic province, or granitic massif. The underlying crust need not be enriched in uranium. The source of the uranium may be from outside the province a considerable distance and geologically and tectonically separate from the province. Mineralization may have taken place in one or more episodes producing one or more types of uranium deposits.

Some deposits of 500 tons or more $\mathrm{U}_{3} \mathrm{O}_{8}$ occur outside the defined uranium provinces, and they probably are indicators of other poorly defined provinces. The unconformity-related Kiggavik cluster, Canada; Swanson cluster, Virginia, U.S.A.; and isolated clusters in Mexico (pl. 1) are examples.

There are several notable concentrations of uranium where uranium either has not been recovered in economic amounts or cannot be recovered at all in the foreseeable future. The most prominent example is the uraniferous Chattanooga Shale in Tennessee in the United States (Swanson, 1961), which is a metallogenic uranium province but because of its grade of 0.007 percent uranium has little economic potential and thus is not included as a uranium province in this report. Likewise, the uraniferous Phosphoria Formation in Idaho and adjacent States, which has yielded very little uranium, is not considered in this report.

\section{DESCRIPTION OF URANIUM PROVINCE MODEL}

For this study, a descriptive model for uranium mineral provinces was designed to capture the broad tectonogeologic setting of spatially and genetically related uranium deposits. The format of this model differs from that of the mineral deposit model of Cox and Singer (1986) with the emphasis on larger scale attributes of a group of deposits (clusters) rather than attributes related to individual deposits. In this regard, the province model probably has wider application for exploration in large regions and the discovery of new districts and provinces throughout the world. Sixteen descriptive attributes are listed. The descriptions of these attributes define the Uranium Province Model in the following format:

\section{Uranium Province Model}

Brief Description. Describe in telegraphic style the province's uranium deposit cluster distribution relative to regional features that define the natural boundaries of the province.

Key Deposit Clusters, Districts, Mineral Belts. Name examples of the prominent clusters, districts, and (or) mineral belts.

Types of Deposits. List names of world deposit types given in Nuclear Energy Agency and International Atomic Energy Agency (1992).

Cluster Size and Grade Ranges. Express total of clusters in short tons $\mathrm{U}_{3} \mathrm{O}_{8}$ and average grades of clusters in percent $\mathrm{U}_{3} \mathrm{O}_{8}$.

Total Resource Magnitude. Express total of production and reserves in short tons $\mathrm{U}_{3} \mathrm{O}_{8}$.

Tectonostratigraphic Setting. Summarize briefly the formational history of the host rocks and concentration of uranium into deposits relative to tectonic history.

Host Rocks. Name rock types that contain the uranium minerals in decreasing order of importance.

Principal Ages of Host Rocks. Express the geologic age and numerical age range in brackets.

Epochs of Mineralization. Express the time intervals of mineralization from oldest to youngest in same format as ages of host rocks.

Ore Mineralogy. Name the primary uranium ore minerals in decreasing order of abundance; if important, name oxidation uranium minerals separated from primary mineral list by a semicolon. + , mineral always present; \pm , mineral; may be absent.

Associated Ore Elements. Name primary ore elements that have been recovered or are economically recoverable in decreasing order of importance. 
Alteration. Where significant, describe alteration relative to preparation of the host rock, uranium mineralization, and post-mineralization where appropriate.

Probable Sources of Uranium. List proposed source(s) with evidence; add references if more than one proposal.

Mineralizing Solutions. Give general term(s) with main chemical composition; if more than one solution give relation to each other.

Plate Tectonic Relations. Give plate tectonic history relative to formation of host rock, source of uranium, and time of mineralization.

Principal References. List principal references in alphabetical order by author name.

\section{DEFINITIONS AND MODELS OF NORTH AMERICAN URANIUM PROVINCES}

Seven uranium provinces are recognized, defined, and modeled for North America: Blind River-Elliot Lake Uranium Province, Canada (BRELUP); Athabasca Basin Uranium Province, Canada (ABUP); Colorado Plateau Uranium Province, United States (CPUP); Rocky Mountain and Intermontane Basins Uranium Province, United States (RMIBUP); Gulf Coast Uranium Province, United States and Mexico (GCUP); Basin and Range Uranium Province, United States and Mexico (BRUP); and Florida Phosphorite Uranium Province, United States (FPUP) (pl. 1). These provinces contain more than 95 percent of identified potential uranium resources in North America. Several other uranium provinces are suspected but are not defined here because they contain too few known large deposits. Two potential uranium provinces are Thelon Basin, Canada, and the Appalachian Piedmont in Eastern United States (Rast, 1989), which possibly extends into Canada. Extensive exploration in the Thelon Basin, whose geologic history is analogous to that of Athabasca Basin, has disclosed one (Kiggavik, pl. 1; Fuchs and Hilger, 1989) and possibly several more large deposits (Rocky Mountain Scout, 1993; Vlad Ruzicka, Geological Survey of Canada, written commun., 1993). The Appalachian Piedmont region contains large potential uranium resources (U.S. Department of Energy, 1980). A large deposit, the Swanson deposit (pl. 1; Halladay, 1989), is known in the Virginia portion of the Appalachian Piedmont, but others in the region have not been publicly disclosed for political and business reasons. Some of these are economically viable, but concern over uranium mining in Virginia led to laws that, in effect, banned the mining of the Swanson deposit, and this probably curtailed any plans for developing other deposits in this region.

These definitions and models of uranium provinces are two-dimensional; examination in three dimensions and age slices by GIS (Geographic Information Systems) would further refine our understanding of the provinces.

\section{ATHABASCA BASIN URANIUM PROVINCE, CANADA}

\section{DEFINITION}

The Athabasca Basin Uranium Province is defined by the deep localized basin that formed on the Early Proterozoic Laurentian craton (Hoffman, 1988) at the west edge of the Precambrian Shield. The uranium deposits are of the unconformity-related type. In 1988, they yielded about 65 percent of Canadian production and over 20 percent of Western World output (Sibbald and others, 1991). Veins in the Beaverlodge District to the north just outside the Province occur in older rocks $(1,930 \mathrm{Ma})$ and were mineralized earlier $(\approx 1,750 \mathrm{Ma})$ than the unconformity-related deposits (Sibbald and others, 1991; Cumming and Krstic, 1992). The genetic relations of the two types are controversial (Parslow, 1989). The Beaverlodge District is not considered here to be part of the Athabasca Basin Uranium Province. The internal structure of the Athabasca Basin is complex with many northeast-trending faults and shear zones related to positive basement elements that divide the main basin into "sub-basins" in which the Athabasca Group was deposited (Ramaekers, 1981; Sibbald, 1988; Sibbald and others, 1991). The uranium clusters are concentrated in two areas, the major Cluff Lake cluster in the Paleozoic Carswell impact structure and a single cluster of the north edge in the western part of the basin and numerous clusters along the southeastern boundary (fig. 1).

\section{THE MODEL}

Brief Description. Defined by the outcrop of the Athabasca Group of Middle Proterozoic (Paleohelikian, $\approx 1,450$ Ma) age within the Athabasca Basin, uranium deposits related to sub-Athabasca Group unconformity occur as vein structures in fluvial quartzose sandstone of the Athabasca Group but mostly in underlying Early Proterozoic (Aphebian, 1,750 Ma) basement rocks within the Hearne province, a part of Churchill Structural Province, of the Canadian Shield.

Key Deposit Clusters, Districts. Cluff Lake, Key Lake, Cigar Lake, Rabbit Lake, Collins Bay-Eagle Point, McArthur River (P2 North), McClean Lake-Sue zone, Alberta and Saskatchewan Provinces.

Types of Deposits. Unconformity-related deposit.

Cluster Size and Grade Ranges. 650-195,000 tons $\mathrm{U}_{3} \mathrm{O}_{8}, 0.30-16.5$ percent $\mathrm{U}_{3} \mathrm{O}_{8}$.

Total Resource Magnitude. $5.5 \times 10^{5}$ tons $\mathrm{U}_{3} \mathrm{O}_{8}$. 


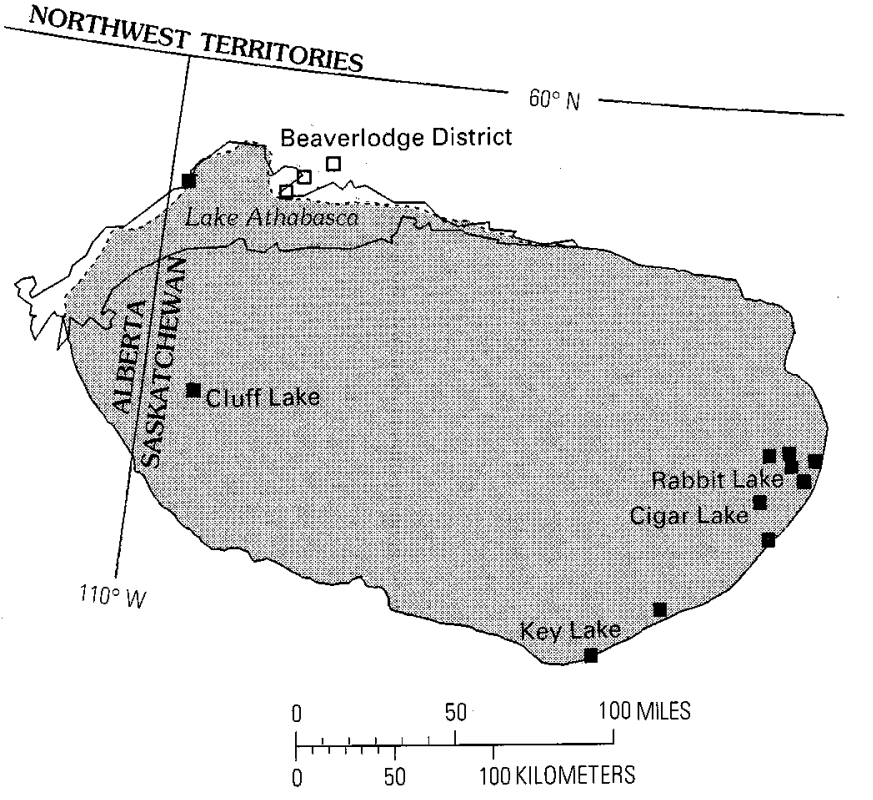

EXPLANATION

\section{URANIUM PROVINCE OUTLINE}

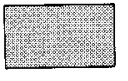

Line solid where well defined, long dash where approximate, short dash where inferred, dotted beneath water

\section{MAJOR URANIUM CLUSTERS}

- Unconformity-related

口 Vein

Figure 1. Details of the Athabasca Basin Uranium Province, Saskatchewan and Alberta, Canada. See plate 1 for location of area and for complete list of uranium cluster types in uranium provinces of North America.

Tectonostratigraphic Setting. The complex, locally disturbed Athabasca Group consisting of four marine transgressive sequences and thick fluvial fans overlies thick regolith on metamorphic and granitic basement rocks of the Hudsonian Western craton and Cree Lake mobile zone. Sedimentation took place in three northeast-trending sub-basins, the Jackfish Basin in the west, the central Minor Basin, and the Cree Basin in the east, each bounded by major faults and (or) positive basement elements.

Host Rocks. Pelitic graphitic gneiss, meta-arkosic sandstone, and pegmatitic granite.

Principal Ages of Host Rocks. Middle Proterozoic, Paleohelikian Athabasca Group, $\approx 1,450 \mathrm{Ma}$; Aphebian basement, $\approx 1,750+$ Ma.

Epochs of Mineralization. Initial episodic mineralization $\approx 1,330-1,380 \mathrm{Ma}(1,514 \pm 18$ at McArthur River); remobilized $\approx 1,280, \approx 1,000, \approx 575, \approx 225 \mathrm{Ma}$.

Ore Mineralogy. Uraninite (pitchblende), coffinite, brannerite, Ni-Co sulfides and arsenosulfides.

Associated Ore Elements. Ni, Co, Au.
Alteration. Sub-Athabasca weathering profile (chloritization, tourmalinization, hematization, illitization, silicification, dolomitization); strong diagenesis, mainly kaolinization and hematization, of Athabasca Group.

Probable Sources of Uranium. Heavy minerals in Athabasca sandstone; graphitic pelitic (marine black shale) gneiss in Aphebian crystalline basement.

Mineralizing Solutions. Hot $\left(150^{\circ}-225^{\circ} \mathrm{C}\right)$ saline, oxidizing formational water related to diagenesis; hydrothermal fluids.

Plate Tectonic Relations. Unconformity developed on rocks of the Hudsonian orogeny $(1,850-1,550 \mathrm{Ma})$ in the Churchill Province as part of a worldwide orogenic event (1,300-1,800 Ma), uplift and erosion followed to fill depressions (sedimentary basins) in the level shield within the north-northeast aligned Athabasca, Thelon, and Borden plates.

Principal References. Bally, 1989; Cameron, 1983; Davidson, 1972; Hoffman, 1989; Lainé and others, 1985; Ramaekers, 1981, 1990; Sibbald, 1988; Sibbald and others, 1991.

\section{BLIND RIVER-ELLIOT LAKE URANIUM PROVINCE, CANADA}

\section{DEFINITION}

The Blind River-Elliot Lake Uranium Province, the smallest province in area, is defined by the part of the Southern Structural Province (Card and others, 1972) within Ontario at the southern margin of the Canadian Shield. The uranium clusters are in a Huronian pericratonic sedimentary basin in the Penokean Fold Belt, which is the western part of this selected portion of the Southern Structural Province; the fold belt extends into the United States, but neither favorable host rocks nor uranium deposits are present there. The deposits are placer concentrations of uranium-bearing minerals in quartz-pebble conglomerate beds formed under anoxyenic conditions near and at the base of the Early Proterozoic sediments. The quartz-pebble conglomerate deposits are very large but generally quite low grade (fig. 2; table $1)$.

\section{THE MODEL}

Brief Description. Defined by a pericratonic sedimentary basin north of the Murray Fault zone in the western portion of Southern Structural Province at the southern margin of the Canadian Shield; host fluvial conglomerate reefs form basal Huronian sedimentary-volcanic pile unconformably mainly on Archean granite.

Key Deposit Clusters. Pronto, Stanleigh, Denison, Agnew Lake (fig. 3).

Types of Deposits. Quartz-pebble conglomerate. 


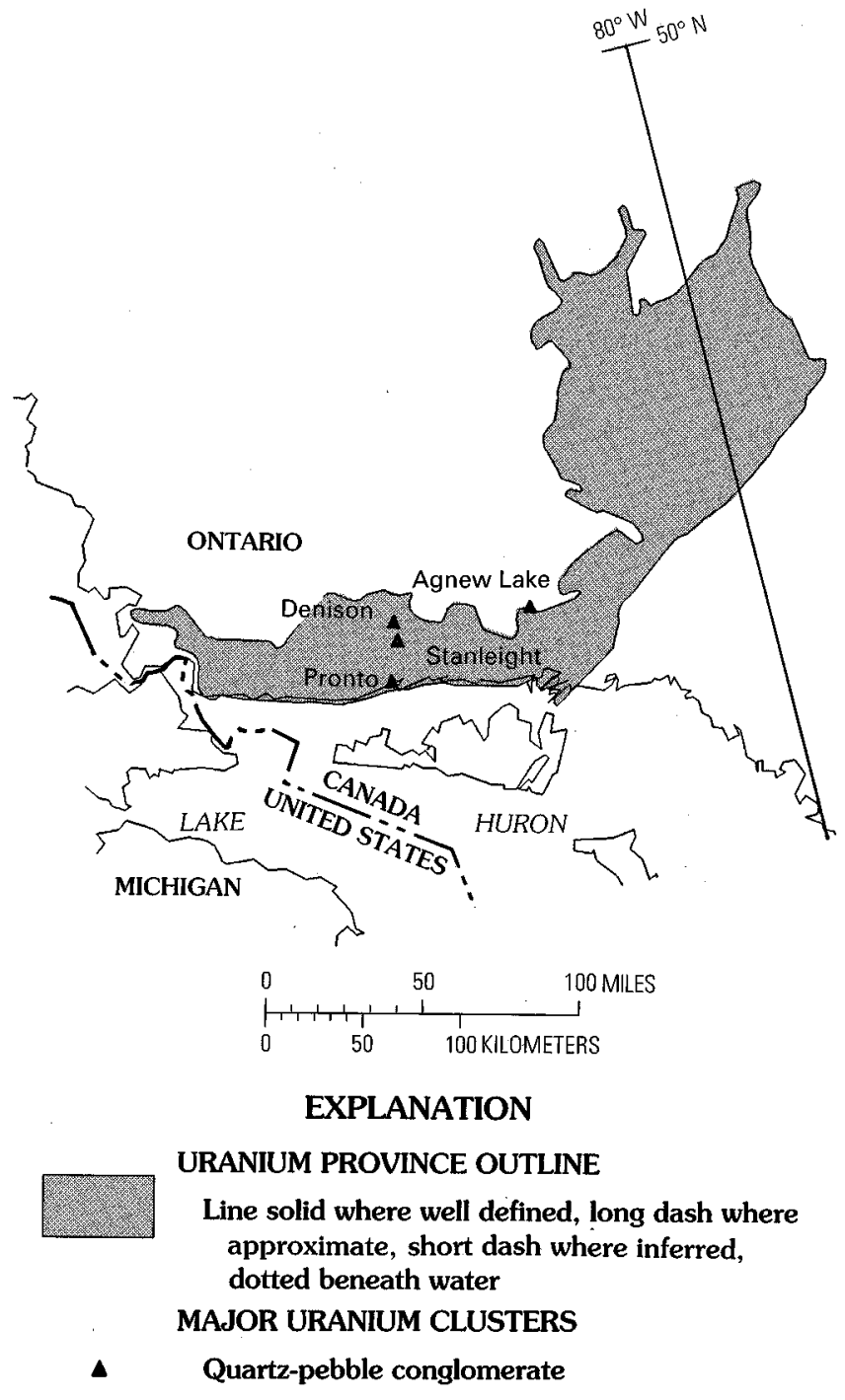

Figure 2. Details of the Blind River-Elliot Lake Uranium Province, Ontario and Quebec, Canada. See plate 1 for location of area and for complete list of uranium cluster types in uranium provinces of North America.

Cluster Size and Grade Ranges. 3,000-240,000 tons $\mathrm{U}_{3} \mathrm{O}_{8}, 0.04-0.125$ percent $\mathrm{U}_{3} \mathrm{O}_{8}$.

Total Resource Magnitude. $3 \times 10^{5}$ tons $\mathrm{U}_{3} \mathrm{O}_{8}$.

Tectonostratigraphic Setting. Host conglomerates (Matinenda Formation) formed under oxygen-deficient conditions in major channel systems in Early Proterozoic basins (now Quirke and Lake Agnew synclines) initiated by crustal extension (rifting) in a cratonic setting at the boundary between the Archean Superior and Grenville structural provinces.

Host Rocks. Quartz-pebble conglomerate and quartzose arenites.

Principal Ages of Host Rocks. Early Proterozoic, 2,500-2,250 Ma.

Epochs of Mineralization. Placer concentration $\approx 2,250 \mathrm{Ma}$; diagenetic modification $\approx 1,850 \mathrm{Ma}$.
Ore Mineralogy. Placer: uraninite, monazite, zircon; authigenic: brannerite, coffinite.

Associated Ore Elements. Th, Y.

Alteration. Post placer concentration of ore minerals-low-grade metamorphism of quartz, chlorite, muscovite, and pyrite matrix.

Probable Sources of Uranium. Pegmatitic granite of Archean Kenoran orogeny (2,750-2,650 Ma) to the north of the sedimentary basin.

Mineralizing Solutions. Stream water carrying detrital uranium-bearing minerals under oxygen-deficient conditions.

Plate Tectonic Relations. Host formation developed in intracratonic rift near volcanic centers south of the basin at the passive continental margin.

Principal References. Card and others, 1972; Robertson, 1976; Roscoe, 1969; Roscoe and Card, 1992; Ruzicka, 1988; Sims and others, 1981.

\section{COLORADO PLATEAU URANIUM PROVINCE, UNITED STATES}

\section{DEFINITION}

The Colorado Plateau Uranium Province was first formally described in 1985 (Granger and Finch, 1988) and later described with more emphasis on tectonics (Finch, 1991). There are 310 uranium clusters in the province of which 53 are large enough to qualify for this study. The large clusters are in the central part of the province so that they in themselves do not define the boundary of the province (pl. 2). The boundaries of the province are drawn on changes in regional structures that bound the Colorado Plateaus physiographic province. These structures expose older sedimentary and Precambrian metamorphic rocks outside the stable plateau block and were in part coeval with widespread Tertiary volcanic activity (Granger and Finch, 1988, fig. 2). The uranium province is bounded on the east by the Laramide Rocky Mountain deformational structures that contrast markedly with the flat-lying formations of the stable Colorado Plateau craton (Bayer, 1983). It is bounded on the north for the most part by the Precambrian Uinta uplift. The western boundary is drawn along the thrust faults and related monoclinal folds and normal faults that define the Basin and Range province. The southern boundary with the Basin and Range is more subtle and broadly defined, especially along the Mogollon Rim.

Within the uranium province, most of the clusters are tabular sandstone deposits hosted by Upper Paleozoic and Mesozoic fluvial sedimentary rocks. They were formed in three major epochs of mineralization: Late Triassic-Early Jurassic, Late Jurassic, and Early Cretaceous. Most of the remainder of clusters are solution-collapse breccia pipes that developed in Pennsylvanian and Permian limestone, 
sandstone, and shale formations and were mineralized with high-grade uranium mainly in Late Triassic time, but two deposits apparently formed in Permian time (260-254 Ma) (Ludwig and Simmons, 1992). Many ores, for example, tabular deposits in the San Juan Basin, were redistributed into roll-front deposits and in veins along faults in Late Cretaceous and early Tertiary time in conjunction with the Laramide deformation. The sources of the uranium for the tabular sandstone and most breccia pipe ores are thought to have been various volcanic arcs to the west and south at the edge of the North American plate, which provided silicic ash for the thick fine-grained units lying above the major Triassic and Jurassic host sandstone layers. The uranium ores in sandstone beds were most likely precipitated by reduction between uranium-bearing ground water and an underlying saline brine.

\section{THE MODEL}

Brief Description. Occupies large part of the Colorado Plateaus physiographic province, an isolated block of the Proterozoic craton since late Paleozoic; contains major uranium deposits in Upper Mississippian to Lower Permian breccia fill in Supai Group and Lower Permian Hermit Shale, and in rocks of the Lower Permian Cutler Group, Upper Triassic Chinle Formation, Middle Jurassic Todilto Limestone Member of the Wanakah Formation, and Upper Jurassic Morrison Formation; bounded by Tertiary volcanic rocks, older sedimentary rocks, and outcropping Precambrian basement rocks.

Key Deposit Clusters, Districts, Mineral Belts. San Juan Basin, Uravan, and Lisbon Valley mineral belts, New Mexico, Colorado, and Utah, respectively; Orphan Lode, Grand Canyon region, Arizona (pl. 2).

Types of Deposits. Tabular sandstone, solution-collapse breccia pipe, limestone.

Cluster Size and Grade Ranges. 500-200,000 tons $\mathrm{U}_{3} \mathrm{O}_{8} ; 0.05-0.60$ percent $\mathrm{U}_{3} \mathrm{O}_{8}$.

Total Resource Magnitude. $6 \times 10^{5}$ tons $\mathrm{U}_{3} \mathrm{O}_{8}$.

Tectonostratigraphic Setting. Fluvial host sandstone facies and overlying thick fine-grained volcaniclastic facies deposited in intracratonic sedimentary basins.

Host Rocks. Quartzose to arkosic sandstone, conglomerate, flow-sand, breccia, limestone.

Principal Ages of Host Rocks. Pennsylvanian/Permian, Early Permian, Late Triassic, Middle and Late Jurassic.

Epochs of Mineralization. Late Triassic-Early Jurassic $\approx 210-200$ Ma, Late Jurassic $\approx 155-150$ Ma, Early Cretaceous $\approx 135 \mathrm{Ma}$; redistribution Tertiary $\approx 60 \mathrm{Ma}$.

Ore Mineralogy. Uraninite, coffinite, montroseite, chalcocite.

Associated Ore Elements. V, Cu.

Alteration. Tabular sandstone ore: bleaching of host sandstone and mudstone by organic reduction of iron minerals. Breccia pipe ore: bleaching by reduction, common calcification, local dolomitization and kaolinization.

Probable Sources of Uranium. Thick volcaniclastic beds overlying ore-bearing horizons, ash derived from volcanic arcs west of the province.

Mineralizing Solutions. Ground water.

Plate Tectonic Relations. Near southwest boundary of the North American plate, and sediment and uranium sources associated with volcanic arcs to west and south during Late Triassic and Late Jurassic; deep burial Cretaceous-early Tertiary as plate developed westward.

Principal References. Finch, 1991, 1992b; Granger and Finch, 1988; McCammon and others, 1986; Wenrich, 1985.

\section{ROCKY MOUNTAIN AND INTERMONTANE BASINS URANIUM PROVINCE, UNITED STATES}

\section{DEFINITION}

The outline of the Rocky Mountain and Intermontane Basins Uranium Province (RMIBUP) is a modification of the Rocky Mountain structural province, which is a reactivated craton characterized by uplifts of the basement and reverse faulting as defined by Bayer (1983). The uranium province is essentially defined by the extent of the Laramide uplifts and basins. Roll-front sandstone uranium deposits formed in the basins, and vein uranium deposits formed in fractured rocks of the uplifts. The Laramide fluvial-lacustrine basins acquired their individuality in latest Cretaceous to Eocene (Gries, 1983). The southern part of the western boundary coincides with the northeast side of the Colorado Plateau Uranium Province, and the north edge of this boundary coincides with the Phanerozoic western Cordilleran of North America. The Rocky Mountain front as shown by Bayer (1983) forms the eastern and northern boundaries of the RMIBUP. The intermontane Powder River Basin lies between the Black Hills and Bighorn Mountains and is included in the uranium province; however, the Williston, Crawford (DeGraw, 1971), and Denver Basins on the High Plains are not intermontane basins and lie outside of the RMIBUP. Large low-grade (0.01 percent uranium), uneconomic lignite uranium deposits occur in the southwestern part of the Williston Basin in South and North Dakota (Denson and Gill, 1965). The large roll-front uranium deposits (Crowe Butte cluster, p1. 1) in the Chadron Formation, White River Group, are in the Crawford Basin. The RMIBUP boundary that excludes the Crow Butte and related deposits is drawn on the north edge of the Black Hills domain in the Trans-Hudson orogeny in contact with the Central Plains orogeny in the Precambrian basement (Sims and others, 1991, fig. 2). The clusters in Weld County, Colo., are in the Upper Cretaceous Fox Hills Formation in 
the Denver Basin. Uranium deposits occur east of the RMIBUP farther to the south in Colorado and New Mexico; all these deposits east of the RMIBUP are in the High Plains physiographic province. The southern tip of the RMIBUP is in contact with the Basin and Range Uranium Province. The southernmost part of the RMIBUP includes the Tertiary volcanic rocks and their uranium clusters in the Rio Grande rift, which might more properly belong in the Basin and Range Uranium Province, but for convenience they are included in the RMIBUP.

The predominant type of uranium deposit is the roll-front sandstone deposit in Tertiary continental fluvial basins developed between uplifts. These ore deposits were formed by oxidizing uranium-bearing ground waters that entered the host sandstone from the edges of the basins. Two possible sources of the uranium were (1) uraniferous Precambrian granite that provided sediment for the host sandstone and (2) overlying Oligocene volcanic ash sediments. Several major uranium deposits occur as veins in Precambrian metamorphic and lower Paleozoic sedimentary rocks outside the Tertiary basins in the central part of the province. These vein deposits also formed during Tertiary time but had a uranium source related to Proterozoic volcanic rocks deposited in a back-arc basin.

\section{THE MODEL}

Brief Description. Boundary coincides with Laramide tectonic province in the southern and middle Rocky Mountains, Wyoming basins, and Black Hills regions; major uranium deposits occur in vein structures in Proterozoic igneous and metamorphic and Paleozoic sedimentary rocks and as sandstone deposits in Cretaceous and Tertiary basinal sediments.

Key Deposit Clusters, Districts. Powder River Basin, Gas Hills, Shirley Basin, Crooks Gap, and Hulett Creek districts, Wyoming; Tallahassee Creek district, Colorado; Schwartzwalder, Pitch, and Los Ochos clusters, Colorado; Hagan Basin, New Mexico (pl. 2).

Types of Deposits. Roll-front sandstone in continental fluvial sandstone; veins in metamorphic, igneous, and sedimentary rocks.

Cluster Size and Grade Ranges. Sandstone: 500-20,000 tons $\mathrm{U}_{3} \mathrm{O}_{8}, 0.04-0.23$ percent $\mathrm{U}_{3} \mathrm{O}_{8}$; vein: 500-5,000 tons $\mathrm{U}_{3} \mathrm{O}_{8}, 0.15-0.48$ percent $\mathrm{U}_{3} \mathrm{O}_{8}$.

Total Resource Magnitude. $3.5 \times 10^{5}$ tons $\mathrm{U}_{3} \mathrm{O}_{8}$.

Tectonostratigraphic Setting. Predominant roll-front uranium ores formed in arkosic and tuffaceous fluvial sandstone formations deposited in small basins developed by Laramide uplifts. Protoliths of the metamorphic hosts for uranium ores deposited in a volcanic back-arc basin environment prior to $1,730 \mathrm{Ma}$.
Host Rocks. Continental fluvial sandstone; metavolcanic and metasedimentary metamorphic rocks; dolomite.

Principal Ages of Host Rocks. Early Proterozoic $(\approx 1,700 \mathrm{Ma})$, Mississippian-Pennsylvanian, Early Cretaceous (144-97 Ma), Eocene (52-36 Ma), Oligocene (36-24 Ma).

Epochs of Mineralization. $70 \mathrm{Ma}, 35-26 \mathrm{Ma}, 3 \mathrm{Ma}$.

Ore Mineralogy. Uraninite, pitchblende, coffinite, carnotite.

Associated Ore Elements. V.

Alteration. Roll-front sandstone ore: oxidation of iron minerals updip from front and reduction of iron minerals downdip along advancing redox interface. Vein ore in metamorphic hosts: carbonate-sericite and hematite-adularia alteration.

Probable Sources of Uranium. Sandstone deposits: Oligocene volcanic ash and (or) Precambrian granite (2,900-2,600 Ma); vein deposits: Proterozoic volcanogenic metamorphic rocks, Oligocene(?) welded tuft.

Mineralizing Solutions. Sandstone: oxygen-bearing ground water; vein: hydrothermal $\left(100^{\circ}-200^{\circ} \mathrm{C}\right)$ fluids.

Plate Tectonic Relations. Uranium mineralization began with inception of Laramide uplift $(\approx 70 \mathrm{Ma})$ and peaked in Oligocene as evidenced by apparent relation of uranium ore to a pervasive Oligocene surface stretching from New Mexico to Montana and Dakotas and associated volcanism related to plate tectonic activity to the west in the Basin and Range province.

Principal References. Chenoweth, 1991; Dickinson, 1981; Epis and others, 1976; Harshman, 1972; Harshman and Adams, 1980; Hausel and others, 1990; Nash, 1988; Olson, 1988; Robinson and Goode, 1957; Wallace and Whelan, 1986.

\section{GULF COAST URANIUM PROVINCE, UNITED STATES AND MEXICO}

\section{DEFINITION}

The Gulf Coast Uranium Province lies along the northwest sector of the Gulf of Mexico in south Texas and adjacent Mexico. The landward extent of Eocene host formations form the western boundary of the province. Potential Tertiary host uranium formations do not extend to present-day shoreline except in Mexico where they strike into the water. For practical reasons, the shoreline of Texas and Mexico is the eastern boundary of the province. The north boundary is based on the farthest northward extent of volcanic ash facies in Eocene and younger rocks. The Eocene, Oligocene, Miocene, and Pliocene host units were formed by megachannel fluvial systems that prograded gulfward into near-shore and eventually true marine sediments. The host units are stacked but rarely are they 


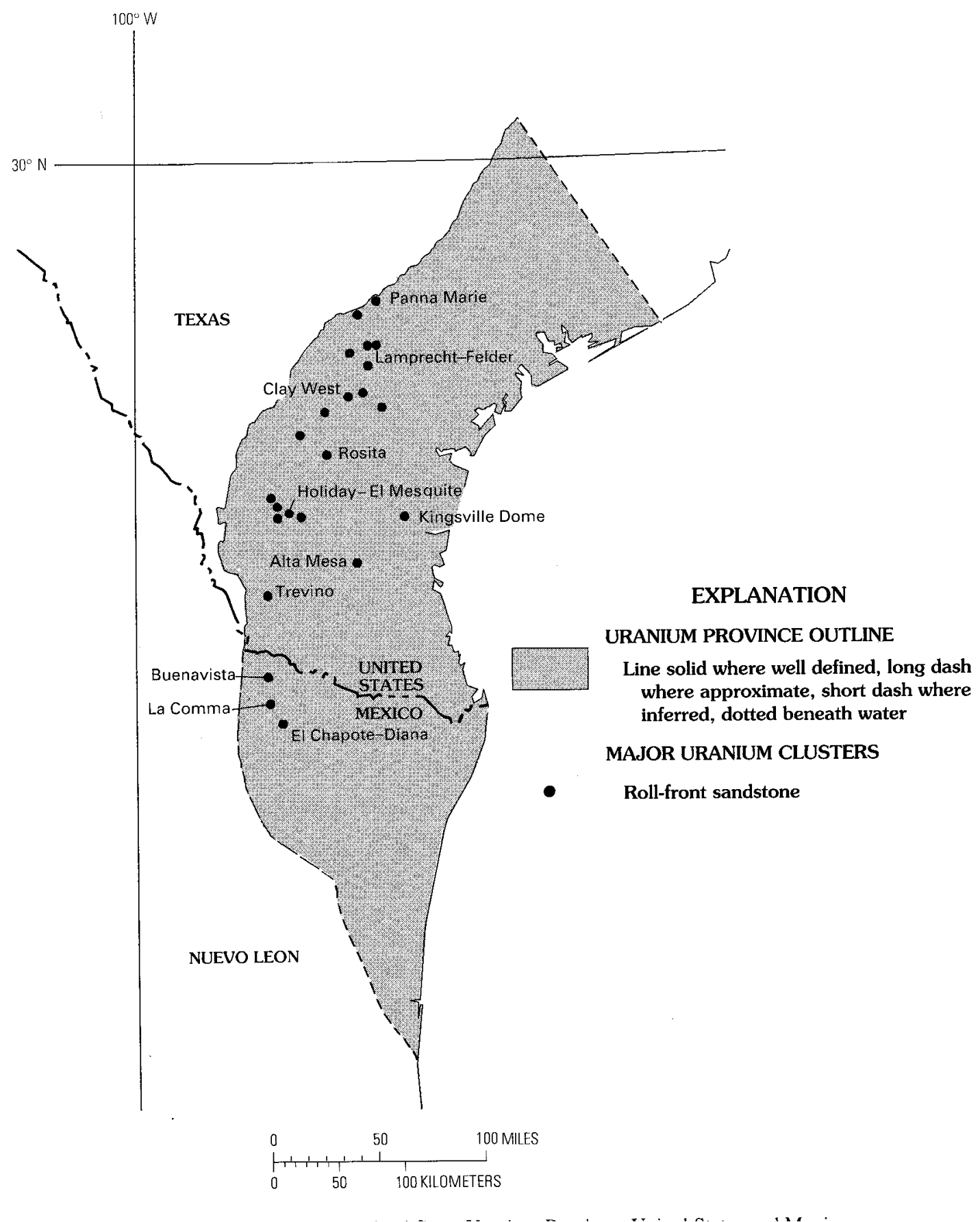

Figure 3. Details of the Gulf Coast Uranium Province, United States and Mexico.

mineralized with uranium so that orebodies overlie one another (Adams and Smith, 1981). A major source of volcanic ash was derived from an Oligocene volcanic arc, probably in the Big Bend country of West Texas (Clark and others, 1982).

All the deposits in the province are marginal marine roll-front sandstone deposits (fig. 3). Carbonaceous plant material needed for reduction is sparse in the host formations. Contemporaneous down-to-coast growth faults are most likely the source of the $\mathrm{H}_{2} \mathrm{~S}$ gas reductant for most of the uranium deposits (Reynolds and Goldhaber, 1983).

\section{THE MODEL}

Brief Description. Broad flat coastal plain in southeast Texas and adjacent Mexico on the northwest flank of the Gulf of Mexico; uranium deposits in Eocene Whitsett, 
Oligocene Frio, Oligocene and Miocene Catahoula, Miocene Oakville, and Pliocene Goliad Formations; bounded updip by older Tertiary rocks and downdip by limit of marine equivalent facies.

Key Deposit Clusters. Panna Marie, Clay West, Holiday-El Mesquite, Lamprecht-Felder, Kingsville Dome, Alta Mesa, and Trevino, Texas; El Chapote-Diana, La Comma, and Buenavista, Nuevo Leon Province, Mexico (fig. 3).

Types of Deposits. Roll-front sandstone of marine sub-type.

Cluster Size and Grade Ranges. 500-10,000 tons $\mathrm{U}_{3} \mathrm{O}_{8} ; 0.04-0.30$ percent $\mathrm{U}_{3} \mathrm{O}_{8}$.

Total Resource Magnitude. $1 \times 10^{5}$ tons $\mathrm{U}_{3} \mathrm{O}_{8}$.

Tectonostratigraphic Setting. Superimposed and stacked Eocene to Pliocene megachannel fluvial systems (also includes modern rivers) that prograded into subsiding gulf; fluvial sequences of each host unit pass into marine facies in short distances gulfward so that rarely do two favorable host units overlie; contemporaneous down-to-coast growth faults, especially those close to most uranium deposits, provided $\mathrm{H}_{2} \mathrm{~S}$ reductant.

Host Rocks. Mixed fluvial-beach facies, quartzose to arkosic permeable unconsolidated sandstones, most organic poor.

Principal Ages of Host Rocks. Eocene, Oligocene, Miocene, Pliocene.

Epochs of Mineralization. Late Oligocene (30-24 Ma), Pliocene (5 Ma).

Ore Mineralogy. Uraninite, coffinite, ilsemannite.

Associated Ore Elements. Mo.

Alteration. Roll-front sandstone ore: oxidation of iron minerals updip from front and reduction of iron minerals downdip along advancing redox interface.

Probable Sources of Uranium. Volcaniclastic sediments, particularly thick volcaniclastic siltstone and shale in the Oligocene and Miocene Catahoula in juxtaposition with older units and updip from younger units.

Mineralizing Solutions. Oxidizing uraniferous ground water passed basinward through permeable sandstone.

Plate Tectonic Relations. Major episodes of plate subduction and spreading in Paleozoic-Mesozoic time created basic homoclinal dip of Gulf Coastal area and uplands for Tertiary fluvial systems; "Andean" volcanic arc inland from the subduction zone at west edge of continent progressed eastward by $40 \mathrm{Ma}$ and regressed westward by $18 \mathrm{Ma}$, coinciding with maximum Oligocene-Miocene volcaniclastic sedimentation, particularly in the Catahoula, which was probably derived from the Oligocene volcanic rocks to the west in the Big Bend region.

Principal References. Adams and Smith, 1981; Clark and others, 1982; Eargle and others, 1975; Galloway and others, 1979; Goodell, 1981, 1985; Reynolds and Goldhaber, 1983; Salas and Nieto, 1991; Worrall and Snelson, 1989.

\section{BASIN AND RANGE URANIUM PROVINCE, UNITED STATES AND MEXICO}

\section{DEFINITION}

The Basin and Range Uranium Province is defined by numerous widely distributed volcanic uranium deposits (for example in Arizona, Wenrich and others, 1990) in late Tertiary volcanic rocks related to back-arc extensional and regional transtensional tectonics that produced the basin-and-range physiography (Zoback and Thompson, 1978). The province has a sharp boundary with the Colorado Plateau Uranium Province, and extending southward the eastern boundary touches the Rocky Mountain front that narrowly divides the Great Plains and the Basin and Range. The northern part of the Rio Grande trough is arbitrarily placed in the Rocky Mountain and Intermontane Basins Uranium Province. In Mexico, the eastern boundary is with the Gulf Coastal Plains. The southern part surrounds the Sierra Madre Occidental (Drewes, 1978; Raisz, 1964; de Cserna, 1989). In the United States, the western boundary is along the east side of the Sierra Nevada batholith and to the north it abuts the Neogene volcanic arc rocks (Bayer, 1983). The northern boundary is with Quaternary volcanic rocks of the Snake River Plain that mark the northern extent of basin-and-range structures shown by Bayer (1983).

Although the Basin and Range Uranium Province is the largest one in area in North America, only four of the numerous uranium clusters in the province are large, but they span the length of the province (pl. 2). Most of the deposits belong to the volcanic class, and only a few are of other types in older rocks. However, sandstone type deposits are commonly found in the volcanic environment.

\section{THE MODEL}

Brief Description. Coincides with the Basin and Range physiographic province, characterized by extensional tectonics and late Eocene-early Miocene ignimbrite volcanism, bounded on the northeast by fold-and-thrust belt and on the west by Mesozoic granite and accreted terranes; major uranium deposits occur in Tertiary volcanic and related sedimentary lacustrine rocks associated with calderas.

Key Deposit Clusters, Districts. McDermitt, Nev.; Marysvale, Utah; Date Creek Basin, Ariz.; Peña Blanca, Chihuahua, Mexico (pl. 2).

Types of Deposits. Volcanic, composite of hydrothermal vein and tabular lacustrine sandstone deposits.

Cluster Size and Grade Ranges. 500-20,000 tons $\mathrm{U}_{3} \mathrm{O}_{8} ; 0.05-0.10$ percent $\mathrm{U}_{3} \mathrm{O}_{8}$. 
Total Resource Magnitude. $4 \times 10^{4}$ tons $\mathrm{U}_{3} \mathrm{O}_{8}$.

Tectonostratigraphic Setting. McDermitt caldera: eruption of ash-flow tuffs and domes, many peralkaline, at the end of the extensional Northern Nevada rift; Marysvale: early Miocene quartz monzonite intrusion followed by hypabyssal granite and uranium mineralization with emplacement of glassy rhyolite dikes; Date Creek Basin: felsic middle Miocene volcanism including rhyolitic flows and ignimbrites, and airfall debris adjacent to the basin contributed to the lacustrine and paludal facies of the host Chapin Wash Formation; Peña Blanca: Eocene rhyolitic ash flow volcanism produced volcaniclastic and ignimbrite hosts from unidentified calderas and Miocene(?) uplift initiated geothermal mineralizing activity.

Host Rocks. McDermitt: andesitic to rhyolitic flows and tuffaceous moat sediments; Marysvale: granite, quartz monzonite; Date Creek Basin: carbonaceous tuffaceous mudstone; Peña Blanca: rhyolitic ignimbrite.

Principal Ages of Host Rocks. McDermitt: Miocene, 18.5-13.5 Ma; Marysvale: early Miocene, 23-18 Ma; Date Creek Basin: early to late Miocene; Peña Blanca: Eocene, 44-37 Ma (pl. 2).

Epochs of Mineralization. McDermitt: $\approx 12 \mathrm{Ma}$; Marysvale: 19-18 Ma; Date Creek Basin: early to middle Miocene; Peña Blanca: Miocene(?).

Ore Mineralogy. Uraninite, coffinite, metatyuyamunite, carnotite, uranophane, jordisite, fluorite, molybdenite, cinnabar.

Associated Ore Elements. Mo, V, F, Hg.

Alteration. Predominant minerals are silica, kaolinite, montmorillonite, and alunite.

Probable Sources of Uranium. Volcanic ash and glass, magmatic system.

Mineralizing Solutions. McDermitt: hydrothermal fluids and hot spring and meteoric waters; Marysvale: hydrothermal magmatic fluids $\left(\approx 200^{\circ} \mathrm{C}\right)$; Date Creek Basin: diagenetic alkaline carbonate lacustrine pore water; Peña Blanca: geothermal convective ground water.

Plate Tectonic Relations. Basin and Range characterized by Tertiary back-arc extensional tectonics and ignimbrite volcanism beginning in Eocene-Oligocene time in the south that changed to a transtensional setting as the Mendocino triple junction migrated northward up the west coast of North America that produced Miocene felsic igneous intrusive and extrusive host rocks and attendant volcaniclastic lacustrine host rocks related to calderas.

Principal References. Bagby, 1986; Càrdenas-Flores, 1985; Cunningham and others, 1982; Dayvault and others, 1985; Goodell, 1981, 1985; Luedke and Smith, 1978a, 1978b, 1981; Otton and others, 1990; Salas and Nieto, 1991; Sherborne and others, 1979; Zoback and Thompson, 1978.

\section{FLORIDA PHOSPHORITE URANIUM PROVINCE, UNITED STATES}

\author{
By Warren I. Finch and James B. \\ Cathcart
}

DEFINITION

The Florida Phosphorite Uranium Province occupies most of the State of Florida and extends barely into Georgia (Cathcart and others, 1984); the boundary is well defined by wide-spaced drilling. Uranium occurs in carbonate fluorapatite and is recovered as a byproduct in the manufacture of phosphoric acid fertilizer. The resources in this province are the largest of any in North America (fig. 4 ). The phosphate beds were deposited during turbulent upwelling and mixing of cool and warm waters in a long period of relative stability of the eastern margin of the North American plate.

\section{THE MODEL}

Brief Description. Defined by the Floridan Plateau and the coastal plains of Florida and southernmost Georgia. Uranium occurs evenly distributed in phosphate rock in the Miocene and Pliocene Bone Valley Formation of the Hawthorn Group and other Hawthorn Group units and is enriched in weathered zones. Uranium is produced as a byproduct of the production of phosphoric acid fertilizer in the Central Florida District .

Key Deposit Clusters, Districts. Central Florida land-pebble District, Polk, Hillsborough, Hardee, and Manatee Counties; North Florida-South Georgia District, Hamilton and Columbia Counties; Northeast Florida, Duval County; East Florida District, Brevard County; South Florida District (pl. 1).

Types of Deposits. Phosphorite.

Cluster Size and Grade Ranges. 90,000-270,000 tons $\mathrm{U}_{3} \mathrm{O}_{8} ; 0.0070-0.0125$ percent $\mathrm{U}_{3} \mathrm{O}_{8}$ (average 0.0090 percent).

Total Resource Magnitude. $1 \times 10^{6}$ tons $\mathrm{U}_{3} \mathrm{O}_{8}$.

Tectonostratigraphic Setting. Relatively stable Floridan Plateau, phosphate deposited in basins adjacent to rising positive areas that caused turbulent mixing of cool, nutrient laden water with warmer surface water. Phosphate and uranium precipitated from ocean water, later reworking, enrichment, and concentration.

Host Rocks. Phosphate pellets in dolomite, clay, and siliciclastic sediments.

Principal Ages of Host Rocks. Miocene, some reworked phosphate in Pliocene and Pleistocene sediments. 
Epochs of Mineralization. Miocene, reworking and acid weathering in Pliocene, Pleistocene, and Holocene. Mobilization of phosphate and uranium at base of weathered zones caused enrichment to 40 percent $\mathrm{P}_{2} \mathrm{O}_{5}$ and 0.050 percent $\mathrm{U}_{3} \mathrm{O}_{8}$.

Ore Mineralogy. Francolite (carbonate fluorapatite). Crandallite, millisite, wavellite, and vivianite in weathered zone.

Associated Ore Element. P.

Probable Sources of Uranium. Sea water.

Mineralizing Solutions. Sea water; later supergene enrichment by acid ground water.

Plate Tectonic Relations. Coastal plains, uplift began in late Oligocene and continued through Pliocene, several transgressions and regressions related to passive plate margin, relatively stable during long time of deposition: related to upwelling adjacent to the Gulf Stream. Floridan Plateau was relatively stable from Miocene to present.

Principal References. Cathcart, 1978; Cathcart and others, 1984; Pool, 1992; Van Kauwanbergh and others, 1990.

\section{DISTRIBUTION OF URANIUM IN NORTH AMERICA}

The identification of uranium concentrated into geologic uranium deposits and the grouping of them into clusters to define uranium provinces illustrates the geographic and geologic distribution of uranium in North America (pls. 1 and 2; figs. 1-3). In order to obtain a sense of the intensity of this distribution, the magnitude of the total size of uranium resources was determined for each province as well as for those uranium resources located outside of the defined provinces. The production and the initial reserves or remaining reserves for each cluster (including small ones not shown in this report), and in some instances for larger areas, were totaled and rounded to obtain an order of magnitude of resources. These are plotted on the graph in figure 4.

The total magnitude of uranium resources for North America is $3 \times 10^{6}$ tons $\mathrm{U}_{3} \mathrm{O}_{8}$ (table 1). The Florida Phosphorite Uranium Province is about 33 percent of this total (fig. 4). The availability of this uranium resource, however, is tied to its recovery as a byproduct (grade 0.009 percent $\mathrm{U}_{3} \mathrm{O}_{8}$ ) of the manufacture of phosphoric acid. The option to recover uranium is dependent on market conditions, and one not commonly taken because the profit margin is generally small. In 1992, production of uranium from phosphorite amounted to 40 percent of U.S. output (Pool, 1993), but recovery of uranium from one operation was discontinued in 1992 and contribution of phosphorite to uranium output was cut in half. The Colorado Plateau share of uranium

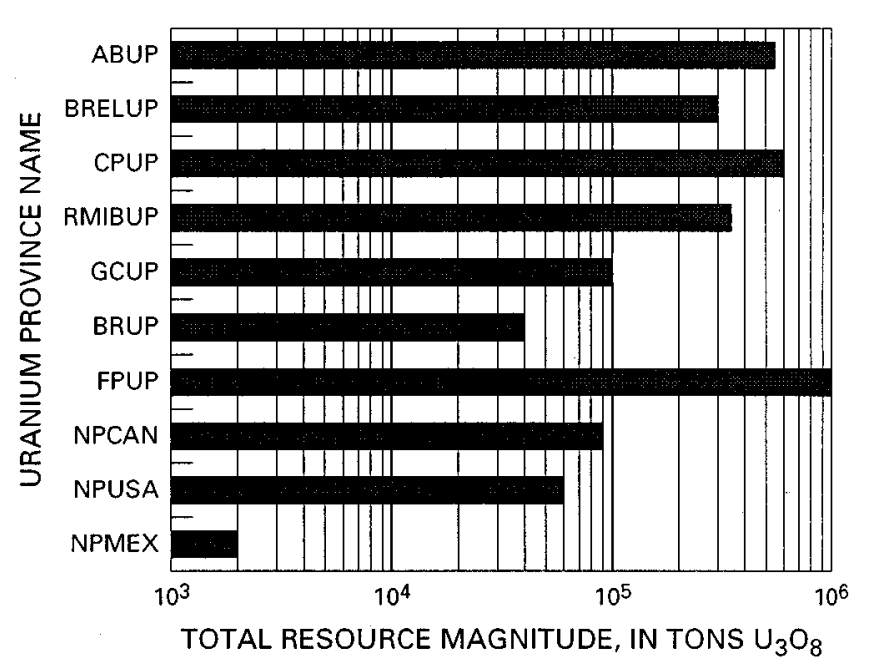

Figure 4. Distribution of uranium (short tons) in North America. ABUP, Athabasca Basin Uranium Province; BRELUP, Blind River-Elliot Lake Uranium Province; CPUP, Colorado Plateau Uranium Province; RMIBUP, Rocky Mountain and Intermontane Basins Uranium Province; GCUP, Gulf Coast Uranium Province; BRUP, Basin and Range Uranium Province; FPUP, Florida Phosphorite Uranium Province; NPCAN, Non-Province Canada; NPUSA, Non-Province United States; NPMEX, Non-Province Mexico.

resources is about 19 percent. About two-thirds of these resources have been produced, and most of the reserves are deeply buried and low-grade sandstone ores (0.02-0.60 percent $\mathrm{U}_{3} \mathrm{O}_{8}$ ), so that its future production capability is limited. On the other hand, the 18 percent in the Athabasca Basin is largely reserves, and it has a bright future, especially because of the high-grade of its ores ( $>1.0$ percent $\left.\mathrm{U}_{3} \mathrm{O}_{8}\right)$. About 11 percent is in the Rocky Mountain and Intermontane Basins Uranium Province. The ores in this province are roll-front sandstone deposits and about one-half of them have been mined. The Blind River-Elliot Lake Uranium Province is nearly 10 percent of the total. The grades of the quartz-pebble conglomerate ores in this province are generally below 0.10 percent $\mathrm{U}_{3} \mathrm{O}_{8}$ and are costly to produce. Only 3 percent is in the Gulf Coast Province (fig. 4). About three-quarters of this has been produced so that its future is limited. The largest province in area but smallest in resources is the Basin and Range with only 0.1 percent, but considering the large number of unexplored calderas and the potential of the Date Creek Basin and nearby basins in western Arizona (Otton and others, 1990), the magnitude of resources in the province is expected to increase markedly in the future. The deposits outside the defined provinces (NPCAN, NPMEX, NPUSA) contain about 5 percent. Several deposits in these non-province areas could be in the future be redefined as a province. 
Table 1. Distribution of uranium in North America.

[NA, not applicable]

\begin{tabular}{|c|c|c|c|c|}
\hline Uranium province name & $\begin{array}{l}\text { Total resource } \\
\text { magnitude } \\
\text { (tons } \mathrm{U}_{3} \mathrm{O}_{8} \text { ) }\end{array}$ & $\begin{array}{l}\text { Area } \\
\left(\mathrm{mi}^{2}\right)\end{array}$ & $\begin{array}{l}\text { Cluster size range } \\
\left.\text { (tons } \mathrm{U}_{3} \mathrm{O}_{8}\right)\end{array}$ & $\begin{array}{l}\text { Cluster grade range } \\
\text { (percent } \mathrm{U}_{3} \mathrm{O}_{8} \text { ) }\end{array}$ \\
\hline Athabasca Basin 1 & $5.5 \times 10^{5}$ & 100,000 & $650-195,000$ & $0.30-16.5$ \\
\hline Blind River-Elliot Lake ${ }^{1}$ & $3 \times 10^{5}$ & 25,000 & $3,000-240,000$ & $.04-.125$ \\
\hline Colorado Plateau & $6 \times 10^{5}$ & 200,000 & $500-200,000$ & $.05-.60$ \\
\hline $\begin{array}{l}\text { Rocky Mountain and Intermontane } \\
\text { Basins }\end{array}$ & $3.5 \times 10^{5}$ & 320,000 & $500-20,000$ & $.04-.48$ \\
\hline Gulf Coast & $1 \times 10^{5}$ & 50,000 & $500-10,000$ & $.04-.30$ \\
\hline Basin and Range & $4 \times 10^{4}$ & 675,000 & $500-20,000$ & $.05-.10$ \\
\hline Florida Phosphorite & $1 \times 10^{6}$ & 30,000 & $90,000-270,000$ & $.007-.0125$ \\
\hline Non-province Canada ${ }^{1}$ & $9 \times 10^{4}$ & NA & $500-25,000$ & $.07-.60$ \\
\hline Non-province U.S.A. & $6 \times 10^{4}$ & NA & $800-22,000$ & $.09-.75$ \\
\hline Non-province Mexico & $2 \times 10^{3}$ & NA & $800-1,200$ & $.03-.08$ \\
\hline Total & $3 \times 10^{6}$ & & & \\
\hline
\end{tabular}

${ }^{1}$ Includes some data modified from Volker Thoste, Bundesanstalt fur Geowissenschaften und Rohstoffe, Hanover, Germany (written commun., 1991).

\section{TECTONOSTRATIGRAPHIC AND PLATE TECTONIC PERSPECTIVE OF THE DISTRIBUTION OF NORTH AMERICAN URANIUM PROVINCES}

Evidence presented in the models points to a unified theme of the development of uranium provinces and the evolution of the North American continent. The early uranium provinces BRELUP and ABUP developed near the edge of the continent before the breakup of "Precambrian Pangea" described by Bally and others (1989) at $\approx 600 \mathrm{Ma}$. These provinces are at the south and west edges, respectively, of the Precambrian Shield. The quartz-pebble conglomerate deposits in the BRELUP formed as paleoplacers under oxygen-deficient conditions in Early Proterozoic, 2,500-2,250 $\mathrm{Ma}$, in an intracratonic rift basin near volcanic centers at the passive continental margin. Deposition of the basal Huronian host fluvial Matinenda Formation and associated felsic and mafic volcanic rocks began at $\approx 2,490 \mathrm{Ma}$ (Roscoe and Card, 1992). The position of the uranium-bearing conglomerate of the Matinenda Formation on the Archean basement floor was apparently controlled by volcanic activity (Roscoe, 1969).

The Middle Proterozoic Athabasca Group, $\approx 1,450 \mathrm{Ma}$, host of the unconformity-related uranium deposits in the ABUP, formed as marine transgressive sequences and thick fluvial fans in a depression that were deposited on the thick regolith previously formed on metamorphic and granitic rocks of the Aphebian basement, $\approx 1,750$ Ma. The unconformity developed on rocks of the Hudsonian orogeny
(1,850-1,550 Ma) in the Churchill Province as part of a worldwide orogenic event $(1,800-1,300 \mathrm{Ma})$. Sedimentation took place in three northeast-trending subbasins within the Athabasca Basin. Furthermore, similar sedimentation took place in the nearby, northeast-aligned Thelon and Border Basins. The ABUP uranium deposits were most likely formed initially by hot saline hydrothermal water related to diagenesis $(\approx 1,330-1,308 \mathrm{Ma})$ and later reconcentrated by hydrothermal events $(\approx 1,280-\approx 1,000, \approx 575$, and $\approx 225 \mathrm{Ma})$ (Cumming and Krstic, 1992). The source of uranium for the deposits was most likely heavy minerals in the Athabasca sandstone and the underlying Aphebian graphitic pelitic gneiss in the vicinity of the deposits. Volcanic sources for sediment in the marine black shale, progenitor of the pelitic gneiss, may have been the initial source of the uranium (Sibbald and others, 1991).

From Late Proterozoic through the end of the Mississippian, North America was mostly submerged, and deposition of marine limestone, dolomite, and shale formations dominated. Most Devonian marine black shales deposited in shallow epicontinental seas in the Central States are uraniferous, and the Upper Devonian and Lower Mississippian Chattanooga Shale contains large noneconomic uranium resources (Swanson, 1961). The immediate source of the uranium was sea water $(\approx 3 \mathrm{ppb} U)$, but volcanic activity in surrounding mountain ranges contributed significant uranium and other metals to the shale. Limited continental Devonian sandstone sediments were shed from Ordovician granite into the Catskill delta to form hosts of minor uranium deposits (Finch, 1967). Continental sedimentation became dominant in Pennsylvanian time, and host rocks for 
large uranium deposits were deposited in Permian and younger periods after continental collision in Permian time (255 Ma).

The CPUP has been a stable craton since late Paleozoic. The Permian, Triassic, and Jurassic host-facies sedimentation was essentially limited to intracratonic basins in the CPUP block; extensions of these stratigraphic units outside the plateau are fine-grained facies unfavorable for uranium deposition. The sources of uranium for deposits in Permian through Jurassic hosts are thought to have been various volcanic arcs to the west and south at the edge of the North American plate (Busby-Spera, 1988; Dickinson, 1981; Granger and Finch, 1988). Three main epochs of mineralization occurred during Late Triassic-Early Jurassic $(\approx 210-200 \mathrm{Ma})$ for Permian and Triassic host rocks, Late Jurassic $(\approx 155-150 \mathrm{Ma})$ for Middle Jurassic host rocks, and Early Cretaceous $(\approx 135 \mathrm{Ma})$ for Late Jurassic host rocks (modified from Finch, 1991). Redistribution of the primary uranium ores took place after the beginning of the Laramide orogeny ( $\approx 70 \mathrm{Ma}$ ) (Finch, 1991).

The Laramide orogeny continued well into the Tertiary, during which time numerous intermontane basins were formed in which Eocene and Miocene host formations were deposited in the Rocky Mountains and Intermontane Basins Uranium Province. In the intervening Oligocene time, a widespread thick blanket of tuffaceous sediments covered the Eocene basinal arkosic sandstone and older rocks below a late Eocene surface of low relief developed on Precambrian and younger rocks. This surface formed during a period of about 10 million years of tectonic and magmatic quiescence described by Epis and others (1976) for central Colorado, which most likely extended into the northern part of the uranium province. Evidence supports the conclusion that the tuffaceous rocks of the White River Formation were the most likely source for the uranium deposits in the Eocene basins (Zielinski, 1983). However, Stuckless (1979) presented evidence that Precambrian granite was a source of uranium adjacent to some of the Wyoming basins. As far south as the Pitch cluster (pl. 2) hosted by Mississippian Leadville Limestone in south-central Colorado, the most likely source for the uranium (Olson, 1988) was Oligocene(?) siliceous ash-flow tuff and waterlaid tuff. Volcanism to the west in the Basin and Range region provided silicic ash for many Tertiary host sediments.

To the south in the Gulf Coast Uranium Province of the United States and Mexico, major sea-floor spreading in late Mesozoic and later Tertiary extension created the basic homoclinal dip of the Gulf Coastal area and uplands for Tertiary fluvial sedimentation (Worrall and Snelson, 1989). At the west edge of North America, by $40 \mathrm{Ma}$ a volcanic arc system related to subduction progressed eastward and regressed westward by 18 Ma coinciding with the maximum
Oligocene-Miocene volcaniclastic sedimentation (Clark and others, 1982). The Catahoula Formation probably derived its volcaniclastic component from the Oligocene volcanics in the Big Bend region of West Texas. These Catahoula volcaniclastic sediments in juxtaposition with major Eocene host rocks and updip from major Miocene and Pliocene hosts were probable sources for most of the uranium deposits in provinces.

To the west and north in North America, the Basin and Range Uranium Province stretches from the Oregon-Nevada border southward into northern Mexico, where sparse but economically important volcanic-type uranium deposits occur in upper Tertiary volcanic hosts related to back-arc extensional tectonics. The tectonostratigraphic settings range in the north from middle Miocene ash-flow tuffs and domes along the Northern Nevada rift, particularly at the McDermitt caldera (Zoback and Thompson, 1978); southward to early Miocene intrusions in the Marysvale district, Utah; farther south to early and late Miocene volcanism that produced rhyolitic flows, ignimbrites, and airfall ash hosting uranium deposits in the Date Creek Basin; and at the south, in Mexico, Eocene rhyolitic ash-flow volcanism that produced volcaniclastic and finally ignimbrite hosts for the Peña Blanca uranium deposits. All these occurrences of volcanic uranium deposits are related to calderas.

Finally, the Florida uraniferous phosphorite beds were deposited over a long period of time in Miocene basins on the coastal plain on the relatively stable Floridan Plateau adjacent to rising positive areas. It should be noted that Florida did not become a part of the North American plate until Late Permian (255 Ma) (Bally and others, 1989). Uplift of the coastal plains began in late Oligocene and continued through Pliocene, with several transgressions and regressions related to the passive plate; the Miocene transgression produced the uraniferous phosphorite beds. Reworking and acid weathering during Pliocene, Pleistocene, and Holocene times resulted in enrichment of the phosphate and uranium.

In conclusion, uranium provinces in North America are generally associated with volcanic activity related to the development of the western margin of North America. The south and west margin of the Canadian Shield formed the leading edge of uranium source development and mineralization from the Proterozoic to the present. The development of favorable hosts and sources for uranium are related to various tectonic elements developed over time. Periods of major uranium mineralization were Early Proterozoic, Late Triassic-Early Jurassic, Early Cretaceous, Oligocene, and Miocene. Tertiary mineralization was the most widespread covering most of Western North America and the southeastern coastal region. 


\section{REFERENCES CITED}

Adams, S.S., and Smith, R.B., 1981, Geology and recognition criteria for sandstone uranium deposits in mixed fluvial shallow marine sedimentary sequences, South Texas-final report: U.S. Department of Energy, Grand Junction Office, Colorado, Bendix Field Engineering Corporation, GJBX-4(81), 146 p.

Bagby, W.C., 1986, Descriptive mode of volcanic U, in Cox, D.P., and Singer, D.A., eds., Mineral deposit models: U.S. Geological Survey Bulletin 1693, p. 162.

Bally, A.W., 1989, Phanerozoic basins of North America, in Bally, A.W., and Palmer, A.R., The geology of North America-An overview: Boulder, Colo., Geological Society of America; The geology of North America, v. A, p. 397-446.

Bally, A.W., Scotese, C.R., and Ross, M.L., 1989, North America-Plate-tectonic setting and tectonic elements, in Bally, A.W., and Palmer, A.R., eds., The geology of North America-An overview: Boulder, Colo., Geological Society of America, The Geology of North America, v. A, p. 1-16.

Bayer, K.C., 1983, Generalized structural, lithologic, and physiographic provinces in the fold and thrust belts of the United States (exclusive of Alaska and Hawaii): U.S. Geological Survey Special Map, scale 1:2,500,000.

Busby-Spera, C.J., 1988, Speculative tectonic model for the early Mesozoic arc of the southwest Cordilleran United States: Geology, v. 16, p. 1121-1125.

Cameron, E.M., ed., 1983, Uranium exploration in Athabasca Basin: Geological Survey of Canada Paper 82-11, 310 p.

Card, K.D., Church, W.R., Franklin, J.M., Frarey, M.J., Robertson, J.A., West, G.F., and Young, G.M., 1972, The southern province, in Price, R.A., and Douglas, R.J.W., eds., Variations in tectonic styles in Canada: Geological Association of Canada Special Paper 11, p 335-380.

Càrdenas-Flores, D., 1985, Volcanic stratigraphy and U-Mo mineralization of the Sierra de Peña Blanca district, Chihuahua, Mexico, in Uranium deposits in volcanic rocks, Proceedings of a Technical Committee Meeting, El Paso, Texas, 2-5 April 1984: International Atomic Energy Agency, Vienna, IAEA-TC-490/31, p. 125-136.

Cathcart, J.B., 1978, Uranium in phosphate rock: U.S. Geological Survey Professional Paper 988-A, p. A1-A6.

Cathcart, J.B., Sheldon, R.P., and Gulbrandsen, R.A., 1984, Phosphate rock resources of the United States: U.S. Geological Survey Circular 888, 48 p.

Clark, K.F., Foster, C.T., and Damon, P.E., 1982, Cenozoic mineral deposits and subduction-related magmatic arcs in Mexico: Geological Society of America Bulletin, v. 93, p. 533-544.

Chenoweth, W.L., 1991, A summary of uranium production in Wyoming, in Frost, B.R., and Roberts, Sheila, Mineral resources of Wyoming: Wyoming Geological Association Forty-Second Field Conference Guidebook, Laramie, Wyoming, September 14-18, 1991, p. 169-179.

Cox, D.P., and Singer, D.A., eds., 1986, Mineral deposit models: U.S. Geological Survey Bulletin 1693, 379 p.
Cumming, G.L., and Krstic, D., 1992, The age of unconformity-related uranium mineralization in the Athabasca Basin, northern Saskatchewan: Canadian Journal of Earth Science, v. 29 , no. 8, p. 1623-1639.

Cunningham, C.G., Ludwig, K.R., Naeser, C.W., Weiland, E.K., Mehnert, H.H., Steven, T.A., and Rasmussen, J.D., 1982, Geochronology of hydrothermal uranium deposits and associated igneous rocks in the eastern source area of the Mount Belknap Volcanics, Marysvale, Utah: Economic Geology, v. 77 p. 453-463.

Davidson, A., 1972, The Churchill Province, in Price, R.A., and Douglas, R.J.W., eds., Variations in tectonic styles in Canada: Geological Association of Canada Special Paper 11, p. $381-433$

Dayvault, R.D., Caster, S.B., and Berry, M.R., 1985, Uranium associated with volcanic rocks of the McDermitt caldera, Nevada and Oregon, in Uranium deposits in volcanic rocks, Proceedings of a Technical Committee Meeting in Uranium in Volcanic Rocks, International Atomic Energy Agency, El Paso, Texas, 2-5 April 1984: Vienna, Austria, International Atomic Energy Agency, p. 379-409.

de Cserna, Zolton, 1989, An outline of the geology of Mexico, in Bally, A.W., and Palmer, A.R., eds., The geology of North America-An overview: Boulder, Colo., Geological Society of America, The geology of North America, v. A, p. 233-264.

DeGraw, H.M., 1971, The pre-Oligocene surface in western Nebraska-Its relation to structure and subsequent topographies, in Guidebook to the Late Pliocene and Early Pleistocene: Conservation Division, Nebraska Geological Survey, April 1971, p. 13-21.

Denson, N.M., and Gill, J.R., 1965, Uranium-bearing lignite and carbonaceous shale in the southwestern part of the Williston basin-a regional study, with a section on heavy minerals by W.A. Chisholm: U.S. Geological Survey Professional Paper 463, 75 p., 19 pls., 25 figs., 12 tables.

Dickinson, W.R., 1981, Plate tectonic evolution of the southern Cordillera, in Dickinson, W.R., and Payne, W.D., eds., Relations of tectonics to ore deposits in the southern Cordillera: Arizona Geological Society Digest, v. 14, p. 113-135.

Drewes, Harald, 1978, The Cordilleran orogenic belt between Nevada and Chihuahua: Geological Society of America Bulletin, v. 89, p. 641-657.

Eargle, D.H., Dickinson, K.A., and Davis, B.O., 1975, South Texas uranium deposits: American Association of Petroleum Geologists Bulletin, v. 59, no. 5, p. 766-779.

Epis, R.C., Scott, G.R., Taylor, R.B., and Chapin, C.E., 1976, Cenozoic volcanic, tectonic, and geomorphic features of central Colorado in Epis, R.C., and Weimer, R.J., eds., Studies in Colorado field geology: Professional Contributions of Colorado School of Mines, no. 8, p. 323-338.

Ferguson, John, and others, 1988, Panel 1, The concept of uranium provinces and their mode of Formation, in International Atomic Energy Agency, 1988: p. 439-442.

Finch, W.I., 1967, Geology of epigenetic uranium deposition in sandstone in the United States: U.S. Geological Survey Professional Paper 538, $121 \mathrm{p}$. 
1991, Maps showing distribution of uranium deposits in the Colorado Plateau uranium province-A cluster analysis: U.S. Geological Survey Miscellaneous Field Studies Map MF-2080, scale 1:2,500,000.

1992a, Uranium provinces in North America, in Abstracts, 29th International Geological Congress, Kyoto, Japan, 24 August-3 September 1992: v. 1, Symposia I-3-42, Evolution of metallogenic provinces, p. 196.

1992b, Descriptive model of solution-collapse breccia pipe uranium deposits, in Bliss, J.D., ed., Developments in mineral deposit modeling: U.S. Geological Survey Bulletin 2004, p. 33-35.

Finch, W.I., Molina, P., Naumov, S.S., Ruzicka, V., Barthel, F., Thoste, V., Müller-Kahle, E., and Tauchid, M., 1995, World distribution of uranium deposits, First edition: Vienna, Austria, International Atomic Energy Agency STI/PUB/995. ISBN 92-0-004095-0, scale 1:30,000,000.

Fuchs, H.D., and Hilger, W., 1989, Kiggavik (Lone Gull)—An unconformity related uranium deposit in the Thelon Basin, Northwest Territories, Canada, in Uranium resources and geology of North America, Proceedings of a Technical Meeting Organized by the International Atomic Energy Agency and held in Saskatoon, Canada, 1-3 September 1987: International Atomic Energy Agency IAEA-TECDOC-500, p. 429-454.

Galloway, W.E., Finley, R.J., and Henry, C.D., 1979, South Texas uranium province geologic perspective: University of Texas, Austin, Bureau of Economic Geology, Guidebook 18, 81 p.

Goodell, P.C., 1981, Geology of the Peña Blanca uranium deposits, Chihuahua, Mexico, in Goodell, P.C., and Waters, A.C., eds., Uranium in volcanic and volcaniclastic rocks: American Association of Petroleum Geologists, Studies in Geology 13, p. 275-291.

1985, Chihuahua City uranium province, Chihuahua, Mexico, in Uranium deposits in volcanic rocks, Proceedings of a Technical Committee Meeting, El Paso, Texas, 2-5 April 1984: International Atomic Energy Agency, Vienna, IAEA-TC-490/19, p. 97-124.

Granger, H.C., and Finch, W.I., 1988, The Colorado Plateau Uranium Province, U.S.A., in Recognition of Uranium Provinces, Proceedings of a Technical Committee Meeting on Recognition of Uranium Provinces, London, England, 18-20 September, 1985: Vienna, Austria, International Atomic Energy Agency, p. 157-193.

Gries, R.R., 1983, North-south compression of Rocky Mountain foreland structure, in Lowell, J.D., ed., Rocky Mountain foreland basin and uplifts: Rocky Mountain Association of Geologists, 1983, p. 9-32.

Halladay, C.R., 1989, The Swanson uranium deposit, Virginia-U-P albitite deposit, in Uranium resources and geology of North America, Proceedings of a Technical Meeting Organized by the International Atomic Energy Agency and held in Saskatoon, Canada, 1-3 September 1987: International Atomic Energy Agency IAEA-TECDOC-500, p. 519.

Harshman, E.N., 1972, Geology and uranium deposits, Shirley Basin area, Wyoming: U.S. Geological Survey Professional Paper 745, $82 \mathrm{p}$.

Harshman, E.N., and Adams, S.S., 1980, Geology and recognition criteria for roll-type uranium deposits in continental sandstones-Final report: U.S. Department of Energy, Grand Junction Office, Colorado, GJBX-1(81) 181 p.
Hausel, W.D., Harris, R.E., King, J.K., and Sutherland, W.M., 1990, Metallic and radioactive minerals and lapidary materials of the Powder River Basin and adjacent uplifts, Wyoming: Geological Survey of Wyoming Map Series 32, scale 1:500,000.

Hoffman, P.F., 1988, United plates of America, the birth of a craton; Early Proterozoic assembly and growth of Laurentia: Annual Reviews of Earth and Planetary Sciences, v. 16, p. 543-603.

1989, Precambrian geology and tectonic history of North America, in Bally, A.W., and Palmer, A.R., eds., The Geology of North America-An overview: Boulder, Colo., Geological Society of America, The Geology of North America, v. A, p. 447-512.

International Atomic Energy Agency, 1988, Recognition of Uranium provinces: Vienna, Austria, Proceedings of a Technical Committee Meeting, London, 18-20 September 1985, International Atomic Energy Agency, 457 p.

Klepper, M.R., and Wyant, D.G., 1956, Uranium provinces, in Page and others: U.S. Geological Survey Professional Paper 300, p. $17-25$.

Lainé, R., Alonso, D., and Svab, M., eds., 1985, The Carswell structure uranium deposits, Saskatchewan: Geological Association of Canada Special Paper 29, $230 \mathrm{p}$.

Ludwig, K.R., and Simmons, K.R., 1992, U-Pb dating of uranium deposits in collapse breccia pipes of the Grand Canyon region: Economic Geology, v. 87, p. 1747-1765.

Luedke, R.G., and Smith, R.L., 1978a, Map showing distribution, composition, and age of late Cenozoic volcanic centers in Arizona and New Mexico: U.S. Geological Survey Miscellaneous Investigations Series Map I-1091-A, scale 1:500,000.

1978b, Map showing distribution, composition, and age of late Cenozoic volcanic centers in Colorado, Utah, and southwestern Wyoming: U.S. Geological Survey Miscellaneous Investigations Series Map I-1091-B, scale 1:1,000,000.

1981, Map showing distribution, composition, and age of late Cenozoic volcanic centers in California and Nevada: U.S. Geological Survey Miscellaneous Investigations Series Map I-1091-C, scale 1:1,000,000.

McCammon, R.B., Finch, W.I., Kork, J.O., and Bridges, N.J., 1986, Estimation of uranium endowment in the Westwater Canyon Member, Morrison Formation, San Juan Basin, New Mexico, using a data-directed numerical method, in Turner-Peterson, C.E., Fishman, N.S., and Santos, E.S., eds., A basin analysis case study - The Morrison Formation, Grants Uranium region, New Mexico: American Association of Petroleum Geologists, Studies in Geology 22, p. 331-355.

Nash, J.T., 1988, Geology and geochemistry of the Pitch uranium mine area, Saguache County, Colorado: U.S. Geological Survey Professional Paper 1797, 38 p.

Nuclear Energy Agency and International Atomic Energy Agency, 1992, 1991 uranium resources, production and demand: Paris, Organization for Economic Cooperation and Development, $255 \mathrm{p}$.

Olson, J.C., 1988, Geology and uranium deposits of the Cochetopa and Marshall Pass Districts, Saguache and Gunnison Counties, Colorado: U.S. Geological Survey Professional Paper 1457, $44 \mathrm{p}$.

Otton, J.K., Bradbury, J.P., Forester, R.M., and Hanley, J.H., 1990, Paleontological analysis of a lacustrine carbonaceous uranium 
deposit at the Anderson mine, Date Creek basin, west-central Arizona (U.S.A.): Ore Geology Reviews, v. 5, p. 541-552.

Parslow, G.R., 1989, Basement geochemistry and possible links between "Beaverlodge" and "Athabasca" type uranium mineralization, in Uranium resources and geology of North America, Proceedings of a Technical Committee Meeting organized by the International Atomic Energy Agency and held in Saskatoon, Canada, 1-3 September 1987: Vienna, Austria, International Atomic Energy Agency IAEA-TECDOC-500, p. 321.

Pool, T.C., 1992, Uranium-Is the worst over?: Engineering and Mining Journal, v. 193, p. WW-45-47.

1993, Uranium, politics, politics, politics!: Engineering and Mining Journal, v. 194, March, p.WW-60-63.

Raisz, Erwin, 1964, Landforms of Mexico: Cambridge, Mass., Geography Branch of the Office of Naval Research, Map, Second corrected edition, scale about 1:3,000,00.

Ramaekers, Paul, 1981, Hudsonian and Helikian Basins of the Athabasca region, northern Saskatchewan, in Campbell, F.H.A., ed., Proterozoic basins of Canada: Geological Survey of Canada Paper 81-10, p. 219-233.

1990, Geology of the Athabasca Group (Helikian) in northern Saskatchewan: Saskatchewan Energy and Mines Report 195, $49 \mathrm{p}$.

Rast, Nicholas, 1989, The evolution of the Appalachian Chain, in Bally, A.W., and Palmer, A.R., eds., The geology of North America-An overview: Boulder, Colo., Geological Society of America, The Geology of North America, v. A, p. 323-348.

Reynolds, R.L., and Goldhaber, M.B., 1983, Iron disulfide minerals and the genesis of roll-type uranium deposits: Economic Geology, v. 78, p. 105-120.

Robertson, J.A., 1976, The Blind River uranium deposits-The ores and their setting: Ontario Division of Mines Miscellaneous Paper 65, 45 p.

Robinson, C.S., and Goode, H.D., 1957, Preliminary geologic map of the Hulett Creek uranium mining area, Crook County, Wyoming: U.S. Geological Survey Mineral Investigations Field Studies Map MF-121, scale 1 in.=500 ft.

Rocky Mountain Scout, 1993, North American uranium activity, January, 1993: Casper, WY 82601, 243 South Center, Suite 3, Rocky Mountain Scout, 25 p.

Roscoe, S.M., 1969, Huronian rocks and uraniferous conglomerates in the Canadian Shield: Geological Survey of Canada Paper 68-40, $205 \mathrm{p}$.

Roscoe, S.M., and Card, K.D., 1992, Early Proterozoic tectonics and metallogeny of the Lake Huron region of the Canadian Shield, in Gaál, G., and Schultz, K.J., eds., Precambrian metallogeny related to plate tectonics: Precambrian Research, v. 58, p. 99-119.

Ruzicka, Vladimir, 1988, Geology and genesis of uranium deposits in the early Proterozoic-Blind River-Elliot Lake basin, Ontario, Canada, in Recognition of uranium provinces, Proceedings of a Technical Committee Meeting, International Atomic Energy Agency, London, 18-20 September 1985: Vienna, Austria, International Atomic Energy Agency, p. 107-130.

Salas, G.P., and Nieto, F.C., 1991, Geology of uranium deposits in Mexico, in Salas, G.P., ed., Economic geology, Mexico, The geology of North America: Geological Society of America, v. P-3, p. 161-165.
Selner, G.I., and Taylor, R.B. 1992, System 8, GSMAP, GSMEDIT, GSMUTIL, GSPOST, GSDIG, and other programs Version 8 , for the IBM PC and compatible microcomputers, to assist workers in the earth sciences: U.S. Geological Survey Open-File Report 92-217, 217 p.

Sherborne, J.E., Jr., Buckovic, W.A., DeWitt, D.B., Hellinger, T.S., and Pavlak, S.J., 1979, Major uranium discovery in volcaniclastic sediments, Basin and Range Province, Yavapai County, Arizona: American Association of Petroleum Geologists Bulletin, v. 63, p. 621-646.

Sibbald, T. I.I., 1988, Geology and genesis of the Athabasca Basin uranium deposits, in Recognition of uranium provinces, Proceedings Technical Committee Meeting of Uranium Provinces, International Atomic Energy Agency, London 18-20 September, 1985: Vienna, Austria, International Atomic Energy Agency, p. 61-105.

Sibbald, T.I.I., Quirt, D.H., and Gracie, A.J., 1991, Uranium deposits of the Athabasca Basin, Saskatchewan (Field Trip 11): Geological Survey of Canada Open File 2166, 56 p.

Sims, P.K., Card, K.D. and Lumbers, S.B., 1981, Evolution of early Proterozoic basins of the Great Lakes region; in Campbell, F.H.A., ed., Proterozoic basins of Canada: Geological Survey of Canada Paper 81-10, p. 379-397.

Sims, P.K., Peterman, Z.E., Hildenbrand, T.G., and Mahan, Shannon, Compilers, 1991, Precambrian basement map of the Trans-Hudson Orogen and adjacent terranes, Northern Great Plains, U.S.A.: U.S. Geological Survey Miscellaneous Investigations Series Map I-2214, scale 1:1,000,000, pamphlet, 53 p.

Stuckless, J.S., 1979, Uranium and thorium concentrations in Precambrian granites as indicators of a uranium province in central Wyoming: Contributions to Geology, University of Wyoming, v. 17, no. 2, p. 173-178.

Swanson, V.E., 1961, Geology and geochemistry of uranium in marine black shales, a review: U.S. Geological Survey Professional Paper 356-C, $112 \mathrm{p}$.

U.S. Department of Energy, 1980, An assessment of uranium in the United States of America: U.S. Department of Energy Report GJO-111(80), 150 p., 6 microfiche.

Van Kauwanbergh, S.J., Cathcart, J.B., and McClellan, G.H., 1990, Mineralogy and alteration of the phosphate deposits of Florida: U.S. Geological Survey Bulletin 1914, 46 p.

Wallace, A.R., and Whelan, J.F., 1986, The Schwartzwalder uranium deposit, III-Alteration, vein mineralization, light stable isotopes, and genesis of the deposit: Economic Geology, v. 81, p. $872-888$.

Wenrich, K.J., 1985, Mineralization of breccia pipes in northern Arizona: Economic Geology, v. 80, p. 1722-1735.

Wenrich, K.J., Chenoweth, W.L., Finch, W.I., and Scarborough, R.B., 1990, Uranium in Arizona, in Jenney, J.P., and Reynolds, S.J., eds., Geologic evolution of Arizona: Tucson, Ariz., Arizona Geological Society Digest 17, p. 759-794.

Worrall, D.M., and Snelson, S., 1989, Evolution of the northern Gulf of Mexico, with emphasis on Cenozoic growth faulting and the role of salt, in Bally, A.W., and Palmer, A.R., eds., The geology of North America-An overview: Boulder, Colo., Geological Society of America; The Geology of North America, v. A, p. 97-138. 
Zielinski, R.A., 1983, Tuffaceous sediments as source rocks for uranium-A case study of the White River Formation, Wyoming: Journal of Geochemical Exploration, v. 18, p. 285-306.

Manuscript approved for publication June 19, 1995

Published in the Central Region, Denver, Colorado

Photocomposition by Norma J. Maes

Graphics by Norma J. Maes and Springfield \& Springfield
Zoback, M.L., and Thompson, G.A., 1978, Basin and range rifting in northern Nevada-Clues from a mid-Miocene rift and its subsequent offsets: Geology, v. 6, p. 111-116. 


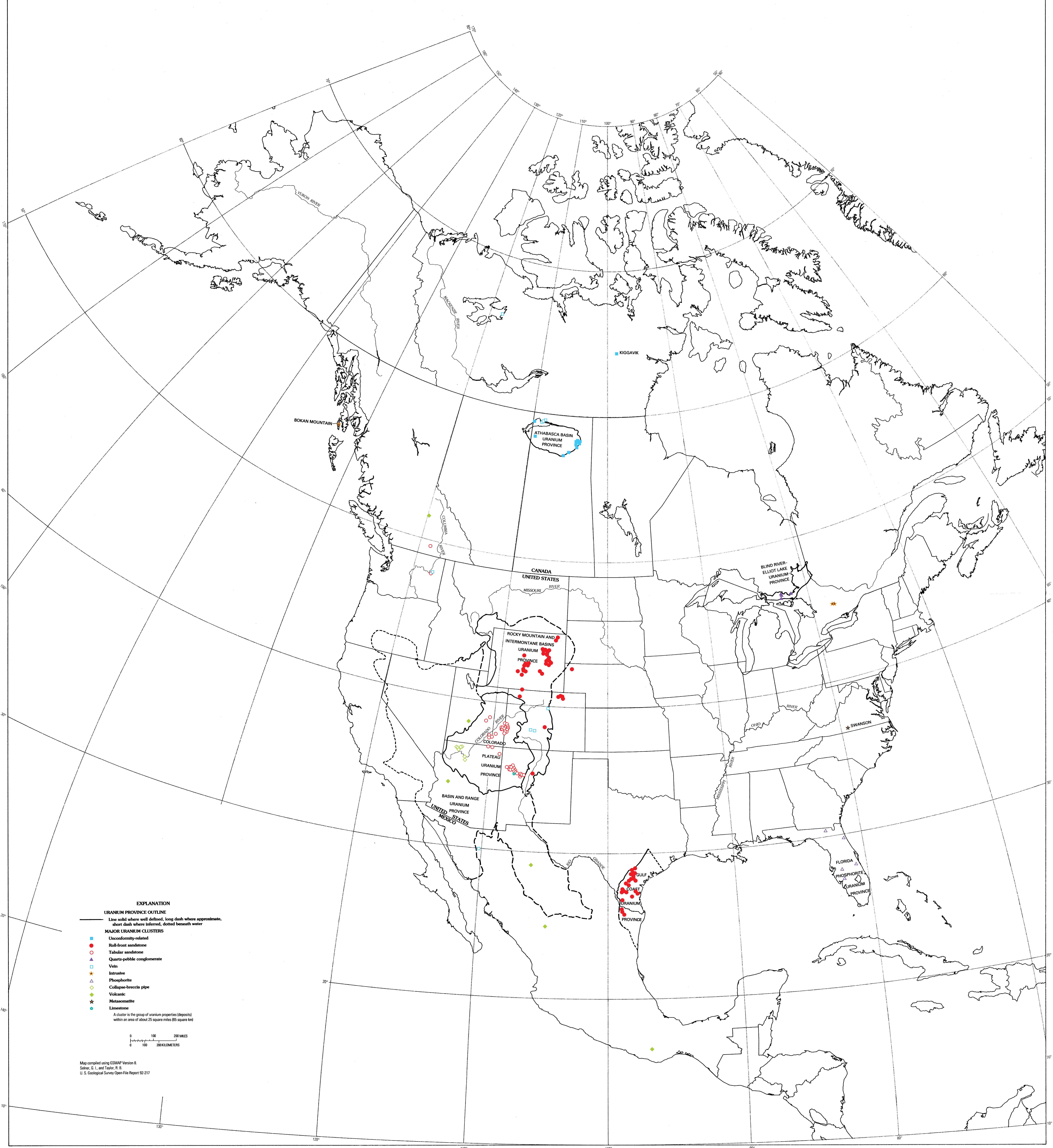




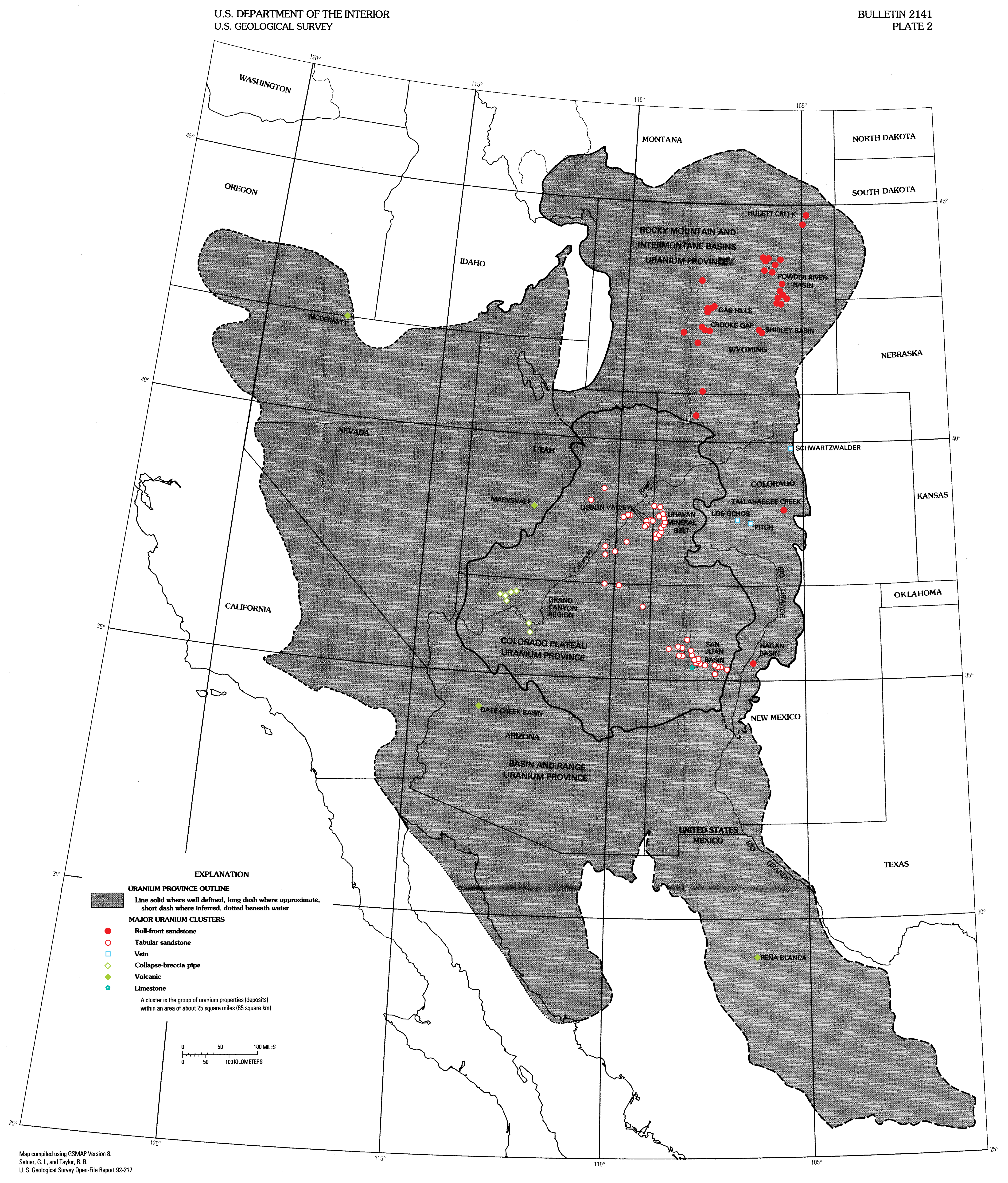

MAP SHOWING DETAILS OF THE COLORADO PLATEAU, ROCKY MOUNTAIN AND INTERMONTANE BASINS, AND BASIN AND RANGE URANIUM PROVINCES

By

Warren I. Finch

1996 